\title{
Rusya'nın Hibrit Savaş Kapasitesinin Kırım ve Donbas Vakaları Üzerinden Analizi
}

\author{
Analysis of Russian Hybrid Warfare Capacity \\ in Crimean and Donbas Crises
}

Cilt: 17

Sayı: 37

$\ddot{o}_{z}$

Çallşma, hibrit savaş olgusunu, Rusya Federasyonu'nun (Bundan böyle bu makalede Rusya Federasyonu'ndan Rusya olarak bahsedilecektir), 2014-2015 yıllarında Doğu Ukrayna (Donbas) ve Kırım üzerinde gerçekleştirdiği harekât üzerinden analiz etmektedir. Seçilen coğrafi bölgenin ve vakaların tarihsel boyutunun anlaşılabilmesi için Ukrayna kimliğine değinilerek, Ukrayna'nın Doğusu ile Batısı arasındaki farklllkkların sebepleri ve tarihsel kökleri vurgulanmıştır. Literatürde birçok yazarın tanımladiğı Hibrit savaş kavramının ne olduğu, tarihsel süreç içerisinde bugün nasıl algılandĭ̆ı açıklanmaya çalışılmış, bu bağlamda kavram karmaşasının önüne geçebilmek için yöntem bakimindan hibrit savass ile ilintili diğer savaş kavramlarına da yer verilmiştir. Sovyet Sosyalist Cumhuriyetler Birliği'nden (SSCB) köhne ve hantal bir miras devralan Rusya'nin, yakın coğrafyasında gerçekleşen egemenlik krizlerini tecrübe ederek şekillendirdiği güvenlik mekanizmast ile hibrit savaş kabiliyetine evrilen güvenlik konsepti bir süreç olarak ele alınmıştır. 2014-2015 Donbas ve Kırım olayların tarihsel ve kavramsal

\footnotetext{
* Ulaştırma Yüzbaşı, Türk Silahlı Kuvvetleri, ORCID: 0000-0002-8265-2015, e-posta:90gokhancin@gmail.com.

Doç. Dr., Polis Akademisi Güvenlik Bilimleri Enstitüsü Suç Araştırmaları Ana Bilim Dalı Başkanı, yazarın yüksek lisans tez danışmanı, ORCID: 0000-0003-36480408, e-posta: hhtekin@hotmail.com.
}

Geliş Tarihi / Submitted: 21.05.2020 Kabul Tarihi / Accepted: 25.01.2021 
Güvenlik Stratejileri

Cilt: 17

Say1: 37

bir derinlikte vaka incelemesi olarak analiz eden bu çalışmanın amacl, Rusya'nın hibrit savaşı nasıl yorumladığını ve "özgün” Ukrayna harekât sahasında nasıl hayata geçirdiğini açılklamaktır.

Anahtar Sözcükler: Hibrit Savaş, Asimetrik Savaş, Donbas, Kırım, Ukrayna.

\section{Abstract}

This study analyses the Eastern Ukraine and the Crimean crises that resulted with de facto boundaries of Ukraine in 2014-2015, from the perspective of Hybrid warfare that implemented by the Russian Federation (Russia). In order to understand the historical aspect of the cases, the causes and historical roots of the difference between Western and Eastern Ukraine has been emphasized by referring the identity of Ukraine. In order to prevent a possible confusion, all the other related concepts which share the method base with hybrid warfare concept, has also been explained. The causes and conditions that generated the hybrid warfare capability which assumed to be possessed by Russia, who is the executor of the Crimea and Donbas cases, have explored. With that aim, the security structure and the security concept which evolved to hybrid warfare capability of the Russia who inherited an obsolete and bulky armed forces from USSR, has discussed in the progress. This study aims to define the Russian interpretation of hybrid warfare in Crimean and Donbas Crises and explore the way of implementation in the Ukrainian battlefield within the context of historical and conceptual aspect as a case study.

Keywords: Hybrid Warfare, Asymmetric Warfare, Donbas, Crimea, Ukraine.

\section{Giriş}

Politik amaçları çatışan iki veya daha fazla sosyal grubun, otoriter bir lider komutası altında teşkilatlandırdıkları savaşçı gruplar arasında gerçekleşen, maksatlı ve ölümcül vakaya 'savaş' denir. Bu tanımın, kayıt altına alınmış ilk örneği MÖ 2700'lerde vuku 


\section{Rusya'nın Hibrit Savaş Kapasitesinin \\ Kırım ve Donbas Vakaları Üzerinden Analizi}

bulmuştur. ${ }^{1}$ Yani insanoğlu yaklaşık beş bin yıldır, rakibinin karşısında gücünün ve yaratıcılığının sınırlarını zorlayarak savaşmaktadır. $\mathrm{Bu}$ mücadelenin sınırlarını genişleten iki temel faktör taktik ve teknolojik gelişim olmuştur. Savaşı kazanacak olan güçlü devletin, modern silahlara ve güçlü bir orduya sahip olması koşulu, doğru fakat eksik bir kabuldür. Teknolojinin yanı sıra taktik kapasitenin de zamanla güncellenmesi, gelişen tehdit algısına ve muharebe sahasının dinamik yapısına paralel olarak geliştirilmesi, hayati bir gerekliliktir.

Bu makale, Rusya'nın hibrit savaş kapasitesini, mekân ve tarih yönünden seçilen vakalar üzerinden sınırlandırmak suretiyle incelemektedir. Evrensel bir tanım oluşturmaya çalışmak, bu çalışmanın kapsamının dışında kalmaktadır. Örnek olay incelemesi üzerinden yapılacak analiz neticesinde Rusya'nın uyguladığı hibrit savaşın belirgin özellikleri tanımlanmaya çalışılacaktır.

Çalışmada öncelikle, hibrit savaş kavramının karşılaştırmalı olarak anlaşılabilmesi için gereken kavramsal çerçeve oluşturulmaya çalışılmıştır. $\mathrm{Bu}$ bağlamda kavram karmaşasının önüne geçebilmek maksadıyla, yöntem bakımından savaş olgusunu tanımlayan konvansiyonel, konvansiyonel olmayan, düzensiz ve asimetrik savaş kavramlarına değinilmiştir. Ardından hibrit savaş kavramının bu çerçeve içerisinde nerede durduğu, sivil ve askerî kaynaklardan istifade edilmek suretiyle belirlenmeye çalışılmıştır.

Müteakiben, seçilen vakaların coğrafi ve toplumsal merkezini oluşturan Ukrayna toplumu içerisindeki fay hatlarına dikkat çekebilmek için Ukrayna'nın kimliği ele alınmıştır. Ukrayna tarihinin, her devrin ideolojisi ile hâkim kültürünün etkisi altında farklı şekillerde tanımlandığı vurgulanmış böylece ortak Ukraynalı kimliğinin toplumun her katmanında inşa edilememesine değinilmiştir. Ayrıca bölgenin etnik, dini ve kültürel haritası yansıtılmaya çalışı1mış, özellikle Doğu Ukrayna'da yaşayan toplumun, kendisini hangi kültüre ve hangi kimliğe daha yakın

\footnotetext{
${ }^{1}$ Claudio Cioffi-Revilla, "Origins and Evolution of War and Politics", International Studies Quarterly, 1996, Vol:40, 1-22, s. 8-9.
} 
206

Güvenlik Stratejileri

Cilt: 17

Sayı: 37

gördüğü vurgulanmıştır. Modern Ukrayna'nın doğusu ile batıs1 arasında var olan farklılıkların, dış müdahaleye engel olması beklenen toplumsal dayanışma bilincini nasıl tehlikeye attığı belirtilmiştir.

Rusya dış politikasının en önemli teminatlarından olan güvenlik mekanizmasının dönüşümüne ve güvenlik konseptinin gelişimine, böylece hibrit savaşa evrilen sürece aktörün penceresinden bakmak için bir başlık daha açılmıştır. Sovyet Sosyalist Cumhuriyetler Birliği'nin (SSCB) dağılmasından itibaren meydana gelen güvenlik krizleri, bahse konu sürecin gelişiminde kritik köşe başları olarak yerini almıştır. Rusya'nın, bu krizlerde elde ettiği tecrübe ile Soğuk Savaş'tan tek süper güç olarak çıkan ABD'nin uzun süren asimetrik mücadeleler karşısındaki yetersizliğini harmanladığı, böylece güçlü bir konvansiyonel silahlı kuvvetler ile nükleer caydırıcılığın teminatı altında daha esnek ve uygulanabilir bir güvenlik sistemi geliştirerek hibrit savaş kabiliyetine evrilen bir istikamet belirlediği görülmektedir.

Son olarak sahada uygulanan hibrit savaş pratiğini detaylarıyla analiz edebilmek için, Kırım'ın Rusya egemenliğine girdiği, Donbas'ın ise yeni bir donmuş çatışma bölgesine dönüştüğü iç savaş sürecinin kronolojisi ve boyutları hibrit savaş perspektifinden açılanmaya gayret edilmiştir. Bu makalenin, seçilen örnek olaylardan hareketle Rus tipi hibrit savaş pratiğinin anlaşılabilmesine imkân sağlaması ve böylece güvenlik çalışmaları literatürüne katkı yapması amaçlanmıştır.

\section{Hibrit Savaşın Diğer Savaş Türleri Arasındaki Yeri}

Hibrit savaş yöntemini anlayabilmek için literatürde var olan diğer savaş yöntemleri ile arasındaki farklılıklar ve benzerliklerin ortaya konması gerekmektedir. Nitekim Savaş biçimlerini, zamana göre (tarih öncesi savaşlar, ilkçağ savaşları, modern savaşlar), kullanılan silahlara göre (denizaltı savaşı, kimyasal savaş, nükleer savaş), kullanılan yönteme göre (konvansiyonel savaş, gerilla savaşı, asimetrik savaş) ve muhtelif kriterlere göre sinıflandırmak mümkündür. ${ }^{2} \mathrm{Bu}$ kriterlerden

\footnotetext{
${ }^{2}$ Ajey Lele, “Asymmetric Warfare: A State vs Non-State Conflict”, Oasis, 2014, 97-111, s. 99.
} 


\author{
Rusya'nın Hibrit Savaş Kapasitesinin \\ Kırım ve Donbas Vakaları Üzerinden Analizi
}

yöntem bakımından savaş başlı̆̆ altına giren hibrit savaşı tanımlamadan önce konvansiyonel, konvansiyonel olmayan, asimetrik ve düzensiz savaş kavramlarına kısaca değinmek, mukayese yapabilmek için yerinde olacaktır.

Savaş kavramının evrimi içerisinde sanayi devriminin, konvansiyonel savaş kavramına yeni bir boyut kazandırmış olduğu söylenebilir. ${ }^{3}$ Fakat konvansiyonel savaşın ilk örnekleri sanayi devrimi ile sınırlı değildir. Konvansiyonel çerçevede cereyan etmiş muharebelerin ilk örnekleri, insanoğlunun devletler kurup varlıklarını profesyonel ordularla korumaya başladığı MÖ ikinci bin yıla kadar uzanmaktadır. ${ }^{4}$ Yaklaşık dört bin yıldır süregelen konvansiyonel mücadelenin çerçevesini, genel geçer kabul gören dört kıstas üzerinden belirlemek mümkündür. Birinci kıstas, konvansiyonel savaşın devletlerarasında gerçekleşen bir münasebet olduğudur. Yani devlet dışı aktörlerin iştirak ettiği silahlı çatışmalar, konvansiyonel savaş tanımının dışında kalmaktadır. İkinci kıstas, silahlı çatışmanın, profesyonel askerlerden oluşan profesyonel bir ordu tarafından icra edilmesidir. Üçüncü kıstas ise meydana gelen silahlı çatışmanın, dönemin evrensel hukuk veya etik kuralları ile sınırlandırılmasıdır. Dördüncü ve son kıstas, savaşın sonunda taraflardan birisinin kesin sonuçlu bir zaferle muharebe sahasından ayrılması veya iki tarafın mutabık kaldığı bir ateşkes ile silahlı çatışma sürecinin sonlandırılmasıdır. ${ }^{5}$

MÖ 5. yüzyılda yaşamış olan Sun Tzu'nun eserlerinde, konvansiyonel olmayan savaşın düşünsel temellerine rastlamak mümkündür. ${ }^{6}$ Modern zamanlarda ise konvansiyonel olmayan taktiklerin,

\footnotetext{
${ }^{3}$ Avi Kober, "Does the Iraq war reflect a phase change in warfare?", Defense \& Security Analysis, 2005, 121-142, s. 123.

${ }^{4}$ Arther Ferrill, The Origins of War from The Stone Age To Alexander The Great, Thames and Hudson, London, 1985, s. 74.

${ }^{5}$ Mark T. Calhoun, "Clausewitz and Jomini Contrasting Intellectual Frameworks in Military Theory", Army History, 2011, 22-37, s 35.

6 Robert J. Bunker, "Unconventional Warfare Philosophers", Small Wars \& Insurgencies, 1999, 136-149, s. 137.
}

Güvenlik Stratejileri

Cilt: 17

Say1: 37 
208

Güvenlik Stratejileri

Cilt: 17

Sayı: 37

milliyetçilik ve sosyalizm gibi ideolojilerle birleşerek "iç savaş", "devrimci savaş", "sınıf savaşı", "politik savaş" gibi kavramlarla anıldığı görülmektedir. ${ }^{7}$ Konvansiyonel olmayan savaşın birlikte anıldığı bahsi geçen isimlendirmeler bir yana, 18. yüzyıl başından itibaren rastladığımız "gerilla" ve "gerilla savaşı" kavramlarının, konvansiyonel olmayan savaş ile adeta özdeşleştiği ve literatüre katkı veren birçok akademisyen tarafından eşanlamlı olarak kullanıldığı görülmektedir. ${ }^{8} \mathrm{Bu}$ kapsamda konvansiyonel olmayan savaşı, "konvansiyonel bir güç tarafindan muharebe sahasındaki doğrudan karşılaşmada kolaylıkla mağlup olabilecek güçsüz rakibin uyguladığı uzun soluklu savaş biçimi”" şeklinde tanımlamak mümkündür. Konvansiyonel olmayan savaşı sürdüren devlet dışı aktörleri kavramın merkezine koyan başka bir tanıma göre konvansiyonel olmayan savaş, "düşmana yönelik gelişen direniş veya ayaklanma hareketini desteklemek amacıyla düzensiz kuvvetler marifetiyle düzenlenen askerî nitelikteki operasyonlar"dır. Bu noktada, olası bir kavram karmaşasını engellemek için konvansiyonel olmayan savaşın düzensiz savaş ile arasındaki ilişkiye açıklık getirmek gerekmektedir. Müteakip satırlarda tanımlanmış olan düzensiz savaş ile konvansiyonel olmayan savaş, aynı nihai amacı taşıyan eylemlerdir. Fakat konvansiyonel olmayan savaş, askerî literatüre göre sadece düzensiz kuvvetlerle ve belirli bir gizlilik içerisinde yürütülen bir faaliyet olarak sınırlandırılmaktadır. düzensiz savaş ise devlet aktörünün yasal görünürlüğü altında icra edilen geniş bir eylem çeşitliliğine sahiptir. Yani askerî literatüre göre, Konvansiyonel olmayan savaşı düzensiz savaş usulleri içerisindeki bir yöntem olarak konumlandırmak mümkündür. ${ }^{9}$

$\mathrm{ABD}$ ve Batılı ülkeler, sahip oldukları konvansiyonel üstünlüklerine rağmen Irak, Afganistan ve Afrika'da 2000'li yılların başından beri süregelen güvenlik problemlerini bertaraf edememişler,

7 Andrew C. Janos, "Unconventional Warfare: Framework and Analysis", World Politics, Vol. 15, 1963, 636-646, s 636.

${ }^{8}$ Robert J. Bunker, agm, s. 138.

${ }^{9}$ U.S. Joint Forces Command and U.S. Special Operations Command, Irregular Warfare: Countering Irregular Threats, Joint Operating Concept, 2010, s. 1.2-1.3. 


\author{
Rusya'nın Hibrit Savaş Kapasitesinin \\ Kırım ve Donbas Vakaları Üzerinden Analizi
}

bu sebeple tehdidi ve tehditle mücadeleyi anlama ve yeniden tanımlama ihtiyacı duymuşlardır. ${ }^{10} \mathrm{Bu}$ ihtiyaca cevaben oluşturulan askerî dokümanlar, düzensiz savaş kavramına 1şık tutmaktadır. Düzensiz savaşın günümüzde halen yaşayan iki cephesi olan Irak ve Afganistan'da y1llardır mücadele eden ABD ordusuna göre düzensiz savaş, devlet ile devlet dişı aktör arasında süregelen bir mücadeledir. $\mathrm{Bu}$ mücadelede amaç, toplum üzerinde itibar ve meşruiyet kazanmaktır. Yani mücadele alanı toplumun algısıdır. Hedef toplumu yanına çekebilmek ya da başka bir ifadeyle kamuoyu desteğini kazanmak esas maksadı oluşturur. Bu maksada ulaşmanın yolu rakibin gücünü, etkinliğini ve iradesini zayıflatmaktan geçer. Bu noktada konvansiyonel bir karşılaşmadan kaçınarak konvansiyonel olmayan bütün yöntemleri kullanmak mübah kabul edilir. ${ }^{11}$ Görüldüğü üzere askerî tasnif, düzensiz savaşı, muharebe sahasında icra edilen tek tip bir askerî eylem ile sınırlamaktan kaçınır. Bilakis muharebe sahasında ve muharebe sahasının dışında sergilenen gayretler bütünü, düzensiz savaşın geniş muhtevasını oluşturmaktadır. Askerî tarihçi Max Boot, düzensiz savaşın MÖ3000'lerden günümüze kadar gelişimini anlattığı makalesinde, Amerika kıtasındaki Kızılderilileri, Avrupalı sömürgeci devletlere karşı savaşan koloni toplumları, kapitalist işgalcilere karşı savaşan komünist gerillaları ve 11 Eylül saldırılarını düzenleyen El Kaide ve benzer terör örgütlerini ise düzensiz savaşın devlet dış1 aktörlerine örnek olarak göstermektedir. Bu aktörlerin, rakibine karşı halkı kazanabilmek için yöntem olarak gerilla savaşını kullandığını belirtmektedir. Buna karşılık devlet aktörünün düzensiz savaşı, propaganda veya halkla ilişkiler olarak bilinen "bilgi savaşı" üzerinden kazanılabileceğini vurgulamaktadır. ${ }^{12}$ Barak Salmoni’ye göre ise düzensiz savaş, doğrudan bir askerî karşılaşmadan kaçınarak, konvansiyonel olmayan metotlar üzerinden düşmanın siyasi iradesini

\footnotetext{
${ }^{10}$ Barak Salmoni, “The Fallacy of 'Irregular' Warfare”, The Rusi Journal, 2007, 1824, s. 18 .

${ }^{11}$ U.S. Joint Forces Command and U.S. Special Operations Command, Irregular Warfare: Countering Irregular Threats, Joint Operating Concept, 2010, s. 1.4-1.5.

${ }^{12}$ Max Boot, "The Evolution of Irregular War: Insurgents and Guerrillas From Akkadia to Afghanistan", Foreign Affairs, 2013, Cilt:92, Say1:2, s. 100-114.
}

\section{9}

Güvenlik Stratejileri

Cilt: 17

Say1: 37 
ve toplum üzerindeki meşruiyetini yıpratmak veya devirmektir. Bahse konu konvansiyonel olmayan metotlar geniş bir yelpazede bulunan,

Güvenlik Stratejileri

Cilt: 17

Sayı: 37 sivil asker işbirliği, barışı koruma, bilgi harekâtı, konvansiyonel olmayan savaş, çatışma sonrası istikrar operasyonları, çok uluslu askerî operasyonlar ve yabancı ülke ile birlikte icra edilen eğitim faaliyetleri gibi karş1lıklı askerî münasebetleri içermektedir. ${ }^{13}$

Asimetrik savaş, güç ve ölçü bakımından birbirine denk olmayan iki rakibin mücadelesini tanımlar. Zayıf olan kuvvetin mücadeleyi, doğrudan karşılaşma halinde mağlup edemeyeceği güçlü rakibinin zafiyetlerine saldırmak suretiyle sürdürmesi, asimetrik savaş olarak adlandırılmaktadır. ${ }^{14}$ Burada asimetrik savaş kavramı ile düzensiz ve konvansiyonel olmayan savaş kavramları arasında benzerlikler olduğu görülmektedir. Askerî literatür, kavramlar arasındaki sınırları net olarak belirleme gayreti içerisinde olsa da akademik literatür ve medyanın benzer bir görüş birliğine sahip olduğunu belirtmek mümkün değildir. $\mathrm{Bu}$ sebeple kavramlar birbirinin yerine kullanılabilmektedir. Her ne kadar anlamlar ve amaçlar birbirine yakın olsa da asimetrik savaşı icracı üzerinden tanımlamak aradaki farklılığı görmeyi mümkün kılabilecektir. Bu bağlamda asimetrik savaşın en belirgin özelliği, ikili bir karşılaşmada çoğunlukla zayıf olan tarafın kullandığı bir yöntem olmasıdır. Buna karşılık konvansiyonel olmayan savaş ile düzensiz savaş, her iki rakibin de başvurduğu yöntemlerdir. Dolayısıyla akademik literatürde çoğunlukla devlet dışı aktör olarak kabul edilen zayıf kuvvetin, hasmı olan devlet aktörüne, zafiyetlerini istismar ederek saldırması asimetrik savaş olarak kabul edilmektedir. ${ }^{15}$ Özellikle 11 Eylül saldırılarından sonraki süreçte ortaya çıkan asimetrik tehdit ortamı üzerinden tarafları değerlendirecek olursak, bir tarafta terör örgütleri, gerilla savaşçıları, organize suç örgütleri, büyük devletlerin sponsorluğunda savaşan

${ }^{13}$ Barak Salmoni, agm, s. 22.

${ }^{14}$ U.S. Joint Forces Command and U.S. Special Operations Command, Irregular Warfare: Countering Irregular Threats, Joint Operating Concept, 2010, s. J.3.

${ }^{15}$ Ajey Lele, agm, s. 103. 


\author{
Rusya'nın Hibrit Savaş Kapasitesinin \\ Kırım ve Donbas Vakaları Üzerinden Analizi
}

taşeron savaşçı gruplar ile karşı tarafta, konvansiyonel anlamda mağlup edilmesi imkânsız güçlü devletler bulunmaktadır. ${ }^{16}$

Afganistan ve Irak'ta, çok kısa bir sürede ve çok az zayiatla gerçekleştirilen konvansiyonel harekâttan sonra karşılaşılan direnç, $\mathrm{ABD}$ güvenlik bürokrasisini, tehdidi yeniden tanımlamaya ve yeni tedbirler geliştirmeye zorlamıştır. Bu refleksin ilk fikri ürünlerinden olan, 2005 tarihli makale, hibrit savaşı ABD perspektifinden tanımlaması bakımından önem arz etmektedir. ${ }^{17}$ ABD Savunma Bakanı James N. Mattis ile akademisyen Frank G. Hoffman'ın geleceğe yönelik öngörülerini barındıran çalışma, asimetrik taktiklerin, hibrit savaş olarak adlandırılan farklı bir evreye geçtiğine değinmektedir. Sadece taktiklerin değil düşmanın da gömlek değiştirdiği, tabiri caizse çeşitlendiği belirtilmektedir. Olası bir hibrit karşılaşmada düşmanı temsil eden aktörün, egemenliğini kaybetmesine rağmen kitle imha silahlarını elinde bulunduran bir devlet ile birlikte hareket eden, motivasyonu yüksek, etnik tabanlı paramiliter bir güç veya yerinden edilmiş radikal teröristlerin birleşiminden oluşabileceği değerlendirilmektedir. ${ }^{18} \mathrm{Bu}$ aktörün teşkilatının ise yönetici ve yönlendirici seviyede kurulmuş hiyerarşik bir politik yapı ile birlikte sahada faaliyet gösteren âdem-i merkezi bir hücre yapılanmasının bileşiminden meydana gelmesi mümkündür. $\mathrm{Bu}$ tür bir organizasyon bünyesinde tertiplenen devlet dışı aktör, karadan havaya ateşlenebilen hava savunma füzeleri gibi modern silah ve teçhizata erişebilme kabiliyetine sahip olup, pusu kurmak, el yapımı patlayıcı kullanmak, suikast düzenlemek gibi taktiklerle başlatabileceği terör eylemlerini kitlesel isyanlara dönüştürebilme potansiyeline sahiptir. Devlet dış1 aktör bu eylemleri sürdürürken başka bir devlet, sahip olduğu ileri teknoloji silah sistemlerini çeşitli hedeflere yönlendirmek,

\footnotetext{
${ }^{16}$ Josef Schroefl ve Stuart J. Kaufman, "Hybrid Actors, Tactical Variety: Rethinking Asymmetric and Hybrid War", Studies in Conflict \& Terrorism, 2014, 862-880, s. 866.

17 James N. Mattis, Frank G.Hoffman, "Future Warfare: The Rise of Hybrid Wars", Proceedings, 2005, Vol.132/11, s. 1-2.

${ }^{18}$ Frank G.Hoffman, Conflict in the 21 Century: The Rise of Hybrid Wars, Potomac Institute, Arlington, 2007, s. 28-30.
}

\section{1}

Güvenlik Stratejileri

Cilt: 17

Say1: 37 
finansal hedeflere siber saldırılar düzenlemek veya konvansiyonel

Güvenlik Stratejileri

Cilt: 17

Sayı: 37 birliklerini konvansiyonel olmayan teşkilatlara dönüşürmek suretiyle bahsi geçen devlet dişı aktörün mücadelesine destek sağlayabilir. Bu noktada, daha önce tarif edilen savaş formlarından farklı olarak, aktörlerin ve taktiklerin birbirinin içine girdiği ve harmanlandığı bu yeni mecranın, hibrit adı altında, günümüzün ve yakın geleceğin muharebe sahasını oluşturacağ öngörülmüştür. $^{19}$

Askerî kaynaklar incelendiğinde hibrit savaşın, bahsi geçen diğerleri gibi özgün bir yöntem olmadığı fakat siyasi maksadı gerçekleştirebilmek için lüzum görülen yerde ve zamanda diğer savaş yöntemleri birlikte kullanmayı gerektiren ve konvansiyonel savaşı bir üst sınır olarak kabul eden bir strateji olduğu vurgulanmaktadır. ${ }^{20} \mathrm{Bu}$ stratejinin gerektirdiği harekât ortamı, farklı aktörlerin bir arada bulunduğu, barış-kriz-savaş evrelerinin birbirine karıştığı, çoğunlukla meskûn mahalde vuku bulan ve sosyal medya sayesinde herhangi yerel bir gelişmenin süratle dünya kamuoyunun gündemine taşınabileceği kaotik bir ortamda tezahür etmektedir. Bahse konu harekât ortamında yerel halk, terör örgütleri, milis kuvvetler, özel güvenlik şirketleri, yabancı savaşçılar, sivil toplum kuruluşları, düzenli askerî birlikler, istihbarat örgütleri ve özel kuvvetler unsurları, birbirlerinin ilgi ve sorumluluk alanlarında faaliyet göstermektedirler. Henüz savaş halinin ilan edilmediği fakat silahlı çatışmanın devam ettiği ve de facto egemenlik alanlarının oluştuğu türden harekât ortamı, hibrit tehdidin içinde bulunduğu ortamı tanımlamaktadır.

2016 yılında, Rusya Genelkurmay Başkanı Valery Gerasimov tarafından Rusya'nın tehdit ve güvenlik algısına dair tespitler yapan bir makale yayınlanmıştır. $\mathrm{Bu}$ makale, Rusya'nın yeni dönem güvenlik konseptine ve Hibrit Savaş anlayışına 1şık tutmaktadır. ${ }^{21}$ Uluslararası

${ }^{19}$ Frank G.Hoffman, Hybrid Warfare and Challenges, Joint Force Quarterly, 2009, s. 34-40.

${ }^{20}$ Kara Kuvvetleri Komutanlığ, TSK Hibrit Harekat Konsepti, Ankara, 2017.

${ }^{21}$ Valery Gerasimov, "The Value of Science is in the Foresight New Challenges Demand Rethinking the Forms and Methods of Carrying out Combat Operations", Military Review, 2016, s. 23-29. 
güvenlik ortamına, “Arap baharı” perspektifinden yaklaşan Gerasimov, politik ve stratejik hedefi elde edebilmek için askerî olmayan yöntemlerin artan önemine dikkat çekmektedir. Arap baharı sürecinde görüldüğü üzere, tamamen barışçıl protestolarla başlayan muhalif gösteriler, çok kısa bir süre içerisinde kanlı iç savaşlara dönüşerek hükümetleri devirmiştir. Yani toplum, savaşın dinamik bir cephesine dönüşerek dış güçlerin işgaline zemin hazırlamış veya ülkeyi kaosa sürükleyen yolu açmıştır. Netice itibarıyla savaşın yıkıcı sonuçları aynı kalmış ama yöntemi değişmiştir. Makalede öne çıkan bir diğer başlık, güvenliğin sınır dışında da sağlanmasıdır. 2012 yılında Bingazi’deki ABD konsolosluğunun uğradığı saldırıyı örnek gösteren Gerasimov, güvenlik sistemini, sınırların dışında da ülke çıkarlarını koruyabilecek bir kabiliyete ve teşkilata kavuşturmak ve gerekli hukuki düzenlemeyi hayata geçirmek gerekliliğinin altını çizmiştir. Son olarak 21 inci yüzyılda barış ile savaş arasındaki çizginin belirsizleştiğine değinen Gerasimov, bu muğlâklığın yeni olmamasına rağmen artık savaşların, güçlü olan tarafın inisiyatifi dışında başlayabildiğini, savaş ile barış arasındaki çizginin bulanıklaştığını, bu sebeple politik ve askerî hedeflere ulaşmada asimetrik yöntemlerin ve askerî olmayan enstrümanların önem kazandığını belirtmektedir. $^{22}$

\section{Ukrayna Kimliğinin Fay Hatları}

Ulusal kimlik, kuruluş mitiyle başlayan ve etnik, kültürel, ekonomik bütünleşme ile tarihsel bir çerçeve içerisinde gelişen bir aidiyettir. Eğitim, din, dil ve kültür gibi ortak değerler ile pekişen kimlik, toplumu bir arada tutan önemli mayalardan birisidir. Genç Ukrayna Devleti'nin bağımsızlıktan sonraki süreçte, tarihi ve coğrafi ayrılıklarını kendi içerisinde eritip toplumsal bir dayanışmayı tam anlamıyla tesis edemediği, doğu ve batısında bulunan iki hâkim kültürün arasında kaldığı görülmüştür. $^{23,24}$

\footnotetext{
22 Andrew Monaghan, "Putin's Way of War: The War' in Russia's Hybrid Warfare", Parameters, 2015, 65-74, s. 70-72.

${ }^{23}$ Jan Germen Janmaat, "Ethnic and Civic Conceptions of the Nation in Ukraine's
}

213

Güvenlik Stratejileri

Cilt: 17

Say1: 37 
Coğrafya, dil, etnik köken, din ve ekonomik yapı gibi farklılıklar,

Güvenlik Stratejileri

Cilt: 17

Sayı: 37
Ukrayna toplumunu birbirinden farklı iki kimliğe bölmüştür. Bunlardan birincisi Ukraynalılar ile Rusların ortak bir etnik kökeni, kültürü ve dili paylaştı̆̆ını savunan ve etnik milliyetçiliği temel alan "Doğu Slav" kimliğidir. Diğer kimlik ise "Kültür Temelli" kimliktir. Ukraynalıları, Ukrayna'nın yerli halkı olarak kabul eden ve Ukrayna kültürünü paylaşan herkesi kucaklayan "kültür temelli" kimlik, emperyal mirası tekrar kurmaya çalışan Ruslaştırma politikasını reddetmektedir. Bu iki kimlik, kimlik inşa etmenin gereklerinden olan "biz" ve "diğerleri" kavramlarını da farklı tanımlamaktadır. Doğu Slav kimliği, biz kavramını, ortak bir medeniyeti ve kültürü paylaşan Ukraynalılar ve Ruslar olarak görürken; kendilerinden başka herkesi diğerleri olarak tanımlamaktadır. Kültür temelli kimlik ise biz kavramını, "Ukrayna devletine sadık olan herkes" şeklinde kapsayıcı bir tanım benimsemektedir. ${ }^{25} \mathrm{Bu}$ kimlik kalıplarının ayrıştığ diğer iki başlı̆̆ da tarih ve kültür olarak belirtmek mümkündür.

Ukrayna tarihi, nesiller boyunca hâkim kültürün ideolojisi doğrultusunda oluşturulan birbirinden farklı müfredatlara göre öğretilmiş̧ir. Bu istikrarsız geçmişin, Ukrayna'da ortak kimlik oluşturma çabalarına olumlu katkı yapamadığını 2014-2015 olaylarında görmek mümkündür. Ukrayna toplumu; Çarlık Rusyası, SSCB ve bağımsız Ukrayna dönemlerinde kendi tarihini üç farkl1 şekilde öğrenmiştir. Bu farkl111klar, yukarıda da belirtildiği üzere Doğu Slav halkları için ortak başlangıç miti olan Kiev Knezliği ile başlamakta fakat sonra çeşitli yol ayrımlarında istikamet değiştirerek farklı güzergâhlardan günümüze gelmektedir. Örneğin 1654 yılında imzalanan Pereyaslav Anlaşması, Ukrayna tarihi içinde farklı yorumlanan hadiselerden birisidir. $\mathrm{Bu}$ anlaşma Çarlık Rusya'sı ve SSCB müfredatına göre Ukrayna'nın

History Textbooks", European Education, 2005, 20-37, s. 34-35.

${ }^{24}$ Taras Kuzio, "Nation Building, History Writing and Competition Over The Legacy of Kyiv Rus in Ukraine", Nationalities Papers, 2005, 29-58.

${ }^{25}$ Glenn Diesen ve Conor Keane, "The Two-tiered Division of Ukraine: Historical Narratives in Nation-building and Region-building", Journal of Balkan and Near Eastern Studies, 2017, 313-329, s. 315. 
Büyük Rusya'ya katılması olarak yorumlanırken, Bağımsız Ukrayna tarihinde, Rusya'nın Ukrayna'yı işgali olarak yorumlanabilmektedir. Bir diğer yorum farkı da Kozak Hetmanı Mazepa için geçerlidir. ${ }^{26}$ 1709'da Çar'a karşı İsveç Kralı'yla işbirliği yaptığı için eski dönemde hain ilan edilen Hetman Mazepa, yeni dönemde halk kahramanı kabul edilerek heykelleri dikilmiştir. Ayrışmaya sebep olan diğer hadiseleri, 1932-33 Holodomor kıtlığı, İkinci Dünya Savaşı, 1944 yılındaki Sibirya sürgünleri, "zafer günü", Stepan Bandera meseleleri olarak sıralamak mümkündür. ${ }^{27}$

Ukrayna'da dini ve kültürel manada da ortak temeller kurulamamıştır. Örneğin Batı Ukrayna, Ortodoks kilisesine kıyasla 2 katı oranda Katolik kilisesine (Roma Katolik Kilisesi ve buna bağlı muhtelif Katolik kiliseler) mensup etnik Ukraynalılar'dan oluşan bir bölgedir. ${ }^{28}$ Buna karşıllk Doğu Ukrayna ise Rus Ortodoks mezhebe mensup, çoğunlukla etnik Rus veya Rusça konuşan Ukraynalılardan oluşan bir bölgedir. Bu etnik dağılımın sebebi, Ukrayna topraklarının doğu ve batısında bulunan üst kültürlerin baskısından kaynaklanmaktadır. Batı'daki komşu Polonya ve Avusturya Macaristan, uzun yıllar süren coğrafi yakınlıktan dolayı Batı Ukrayna'da yerel kültürün şekillenmesine büyük katkıda bulunmuştur. Doğu Ukrayna ise yüzyıllarca Rus kültürünün etkisi altında kalmıştır. ${ }^{29}$ Sadece kültür değil demografi de Doğu Ukrayna'nın etnik haritasının sınırlarını bize göstermektedir. 2001 y1lı verilerine göre Dnipropetrovsk \%17,6, Donetsk \%38,2 Zaporizhzhia \%24,7, Luhansk \%39, Kharkiv \%25,6 oranında Rus etnik nüfusa sahip olup bu rakamlar Ukrayna içerisinde Kırım'dan sonra Rusların en kalabalık etnik azınlık grubu oluşturduğu bölgelerde

\footnotetext{
${ }^{26}$ Taras Kuzio, "Historiography and National Identity among the Eastern Slavs: Towards a New Framework", National Identities, 2001, 109-132, s. 123.

${ }^{27}$ Glenn Diesen ve Conor Keane, agm, s. 317.

${ }^{28}$ Bohdan Hud, "Ukrainian Greek Catholic Church in Galicia (Halychyna): The Creation, The Ban, And The Resurrection. Generall Overview", Proceedings of History Faculty of Lviv University,.2016, 273-293, s. 292.

${ }^{29}$ Stephen Shulman, "The cultural foundations of Ukrainian national identity", Ethnic and Racial Studies, 1999, 1011-1036, s. 1012.
}

\section{5}

Güvenlik Stratejileri

Cilt: 17

Say1: 37 
bulunmaktadır. ${ }^{30}$ Ukrayna'nın Rusya ile kara hududunda bulunan ve

Güvenlik Stratejileri

Cilt: 17

Sayı: 37 "Donetsk Havzası" olarak bilinen maden ve endüstri bölgesi, diğer bir isimlendirme ile Donbas bölgesi olarak anılmaktadır. ${ }^{31} \mathrm{Bu}$ makalenin vaka olarak işlediği ikinci bölge olan Donbas bölgesini tanımlanırken ayrılıkçıların eline geçen ve Rusya sınırında bulunan Donetsk ve Luhansk bölgeleri kastedilmektedir. ${ }^{32}$

\section{Rusya'da Hibrit Savaş Kabiliyetine Evrilen Süreç}

Günümüz Rus dış politikası incelendiğinde, SSCB'nin 1989 yılından itibaren kaybetmeye başladığı nüfuz alanının, halefi olan Rus Devleti için yeniden kazanılması gereken bir zorunluluk olarak değerlendirildiği görülmektedir. Baltık coğrafyasında agresif tatbikatlar ve askerî manevralar gerçekleştiren, Balkanlardaki siyasi atmosfere tesir ettiğine dair ciddi şüpheler bulunan, Orta Doğu coğrafyasına gerçekleştirdiği kuvvet aktarımı ve aldığı inisiyatif ile bölgenin siyasi haritasına doğrudan tesir eden Rusya'nın, uluslararası siyasette ulaştığı konum, 1990'ların başından itibaren maruz kalınan krizler ve uygulanan reform programları neticesinde mümkün olmuştur. $\mathrm{Bu}$ krizler Rus devletinin toprak ve nüfuz kaybetmesi ile sonuçlanmış, müteakiben ortaya çıkan Çeçen Sorunu ve Gürcistan Savaşı, güvenlik mekanizmasını hibrit kabiliyetlere evrilen bir sürece yönlendirmiştir.

Rusya silahlı kuvvetlerindeki reform ihtiyacının sebeplerini, üç başlık altında özetlemek mümkündür. Birinci sebep, SSCB silahlı kuvvetleri olarak 15 devletin ortak güvenlik mekanizmasını temsil eden bu yapının, bağımsızlığını ilan ederek sistemden çıkan devletler sebebiyle yeniden düzenlenme ihtiyacıdır. İkinci sebep, sadece Rusya

${ }^{30}$ Ukrayna Devlet İstatistik Kurumu Resmî Sayfası, "National composition of population", http://2001.ukrcensus.gov.ua/eng/results/general/nationality/ (Erişim Tarihi: 23.01.2021)

31 Britannica Çevrimiçi Ansiklopedi, "Donets Basin", https://www.britannica.com/ place/Donets-Basin (Erişim Tarihi: 23.01.2021)

32 T.C. Dışişleri Bakanlığı Resmî İnternet Sayfası, "Ukrayna'da son durum ve ikili ilişkiler", http://www.mfa.gov.tr/ukrayna_da-son-durum-ve-ikili-iliskiler.tr.mfa (Erişim Tarihi: 23.01.2021) 


\author{
Rusya'nın Hibrit Savaş Kapasitesinin \\ Kırım ve Donbas Vakaları Üzerinden Analizi
}

silahlı kuvvetlerine özgü değil, diğer bütün dünya ordularında da olduğu gibi zaman ilerledikçe konseptte ve doktrinde modern ve güçlü olma zorunluluğudur. Üçüncü ve son sebep ise, SSCB'nin dağılma sürecinde meydana gelen güvenlik krizlerinde, silahlı kuvvetlerin kendisine verilen görevleri yerine getirememiş olmasıdır.

Reform ihtiyacının bir gereği olarak yeni devletin kuruluş arifesinde Rusya Federasyonu Başkanı Boris Yeltsin'in inisiyatifi ile durum tespitine yönelik bir değerlendirme yapılarak çözülmesi gereken sorun sahaları belirlenmiştir. Öncelikli sorun, olası bir üçüncü dünya savaşı senaryosunda, kısa sürede cepheye sevk edilebilecek olan beş milyonluk bir orduya göre kurgulanmış hantal seferberlik sistemi ve bu sisteme göre çeşitli hazırlık seviyelerinde silâhaltında bulundurulan birliklerin vücuda getirdiği silahlı kuvvetler teşkilatıdır. Örneğin 1991 yllında, 132 adet tümenin sadece 20 adedi $\% 70$ hazırlık seviyesinde bulunuyorken kalan 112 tümen $\% 50$ ve $\% 10$ hazırlı seviyelerinde beklemektedir. Yani garajlarda ve depolarda istihdam edilen muazzam bir mevcut bulunmaktadır. Diğer sorun sahaları da önceki sorun ile bağlantılı olarak, 16 bölge komutanlığı altında görev yapan devasa teşkilatın karmaşık yönetimi, bu teşkilatın silah teçhizat ihtiyacını karşılayacak olan savunma sanayinin yetersizliği ve barış zamanında depolarda görev yapan, atıl durumdaki insan ve malzemenin yönetimi başlıklarından oluşmaktadır. $\mathrm{Bu}$ sorunların üstesinden gelebilmek için başlangıçta, silahlı kuvvetlerde küçülmeyi ve kademeli olarak profesyonelleşmeyi öngören bir hal tarzı benimsenmiş fakat ekonomik ve politik gerekçelerden ötürü bu plan tam anlamıyla hayata geçirilememiştir. ${ }^{33}$

Rusya Federasyonu Başkanı Vladimir Putin iktidarı devraldıktan sonra 2002 yılında savunma bakanlığına, KGB'de birlikte çalıştığı Sergei Ivanov'u getirmiştir. Hükümet nezdinde, askerî reformun gerekliliği konusunda iyi niyetli bir bilinç olmakla beraber, önceki savunma bakanları döneminde ciddi anlamda bir ilerleme

\footnotetext{
${ }^{33}$ Aleksey Gayday, "Reform of the Russian Army", Mikhail Barabanov (ed.), Russia's New Army, Centre for Analysis of Strategies and Technologies, Moscow, 2011, 09-33, s. 10-12.
} 
kaydedilememiştir. ${ }^{34}$ Ivanov döneminin ilk icraat1, Genelkurmay

Güvenlik Stratejileri

Cilt: 17

Sayı: 37 Başkanlığını Savunma Bakanlığına bağlamak olmuş, müteakiben Silahlı Kuvvetlerin bütçesi artırılarak istikrar altına alınmış ve eğitim ile tatbikatlara ağırlık verilmiştir. Savunma Bakanının en büyük sınavı Silahlı Kuvvetler içerisindeki yolsuzlukla mücadele olmuş, bazı kurumsal tedbirler alınmasına rağmen Rus güvenlik bürokrasisindeki sorunun kökü olan yolsuzluk meselesi çözüme kavuşturulamamıştır. 2007 yılında görevi Anatoly Serdyukov'a devreden Ivanov'un yeni bakana en büyük mirası da yolsuzluk sorunu olmuştur. ${ }^{35}$

2007'de Savunma Bakanlığı'nı devralan Serdyukov döneminde de Silahlı Kuvvetlerin yolsuzluktan arındırılması öncelikli görev olarak belirlenmiştir. Yolsuzlukla mücadelenin yanı sıra silahlı kuvvetlerin hantal ve köhne yapısının yerine küçük, harbe hazır, profesyonel, süratle intikal ettirilebilen, modern bir teşkilatlanma tasarlanmıștır. Bu kapsamda önce mevcutlarda azaltmaya gidilmiştir. Serdyukov öncesinden başlayan küçülmeyi tarihlerle ifade edecek olursak, 2002 yılında 2,3 milyon olan askerî personel mevcudu, 2008 yılında 1,2 milyon, 2012 y1lında 1 milyona düşürülmüş yani küçülme ve profesyonelleşme politikası istikrarla sürdürülmüştür. ${ }^{36}$ Ayrıca Silahlı Kuvvetler teşkilatı içerisinde, fiili olarak personel istihdam edilen 22000 kadro, 8500 'e düşürülmüştür. ${ }^{37}$

Yolsuzlukla mücadele kapsamında, başta savunma ihtiyaçlarının tedariki olmak üzere, atama, terfi ve görevlendirme gibi personel konularında radikal kararlar alınmış ve Putin'in desteği ile katı bürokrasiye rağmen çok keskin düzenlemeler yapılmıştır. Silahlı Kuvvetlerin ihtiyaç duyduğu malzemeyi tedarik etme yetkisi, yapısal bir düzenleme ile sivil bir kuruma devredilmiş, böylece askerler ihale sürecinden uzaklaştırılmıştır. $\mathrm{Bu}$ yapısal düzenleme ile yolsuzluk

${ }^{34}$ Andrei Makarychev ve Alexander Sergunin, "Russian military reform: institutional, political and security implications", Defense \& Security Analysis, 2013, 356-364, s. 357.

${ }^{35}$ Dale Herspring, "Russian Military Reform and Anatoly Serdyukov", Problems of Post-Communism, 2008, 20-32, s. 21-22.

${ }^{36}$ Dale Herspring, agm, s. 43.

${ }^{37}$ Andrei Makarychev ve Alexander Sergunin, agm, s. 358-359. 


\author{
Rusya'nın Hibrit Savaş Kapasitesinin \\ Kırım ve Donbas Vakaları Üzerinden Analizi
}

sorunu tam anlamıyla ortadan kaldırılamasa da silahlı kuvvetler, yolsuzluk potansiyeli olan bir süreçten uzaklaştırılmış ve sadece ihtiyaçlarını talep ve tarif edecek bir müşteri konumuna getirilmiştir. Tedarik başlığının yanı sıra personel konularında vuku bulan rüşvet ve görevi kötüye kullanma suçlarıyla da mücadele yoluna gidilmiştir. ${ }^{38}$

219

Güvenlik Stratejileri

Cilt: 17

Say1: 37

2010 yılında silahlı kuvvetlerin hiyerarşik yapısında değişikliğe gidilerek, her üç kuvvetin kabiliyetlerinin bir arada toplandığı, üç kademeli bir komuta yapısı belirlenmiştir. SSCB zamanında, Bölge Komutanlığı-Ordu-Kolordu-Alay hiyerarşisine göre teşkilatlandırılmış olan bu yapı, Bölge Komutanlığı-Muharip Komutanlık-Tugay şeklinde yeniden teşkilatlandırılmıştır. Oluşturulan dört adet Bölge Komutanlığ1, Rus anakarasını savunmak üzere, yurt içinde dört bölgede tertiplenmiştir. $\mathrm{Bu}$ tertiplenme ile Rusya içerisinde ve sınırlarındaki muhtemel çatışma bölgelerine süratle intikal edebilecek, harbe hazırlık seviyesi yüksek birlikler kurulması amaçlanmıştır. Yeni teşkilat ve tertiplenme, silahlı kuvvetleri daha etkin bir yapıya kavuşturmasının yanı sıra tasarruf da sağlamış, birliklerin konuşlandığ 1 üs bölgesi sayısı 8000'den 184'e düşürülmüştür. Ayrıca, önceki sisteme göre verilen emrin, en uç icracı birliğe ulaşması için aşması gereken 11 seviye, 3 'e düşürülmüsstür. ${ }^{39}$

2007-2011 döneminde düzenlenen diğer bir fas1l, personel mevcutları ve kalitesi olmuştur. Diğer statülerde de azalma olmakla beraber en çok subay mevcutları azaltılmıştır. General sayısı 1107 'den 886 'ya, albay sayıs 23.663 'den 9114 'e, binbaş1 99.500 'den 25.000 'e ve yüzbaş1 90.000 'den 40.000 'e düşürülmüş, sadece teğmen ve üsteğmen rakamlarında artış olmuştur. Yani toplam subay mevcudu 300.000'den 150.000 'e düşürülmüştür. Fakat eş zamanlı olarak teşkilat ve kadrolarda da gerekli düzenleme yapılmadığı için üç ay sonra 70.000 subay tekrar göreve çağrılmış ve subay mevcutları 220.000 rakamında sabitlenmiştir. Ayrıca Silahlı Kuvvetlerin tamamen profesyonelleşmesi maksadıyla

\footnotetext{
${ }^{38}$ Dale Herspring, "Anatoly Serdyukov and the Russian Military”, Problems of PostCommunism, 2013, 42-58, s. 46-47.

${ }^{39}$ Dale Herspring, agm, s. 51-52.
} 
220

Güvenlik Stratejileri

Cilt: 17

Sayı: 37

sözleşmeli askerlik sistemi hayata geçirilmiş, bu sistemi cazip kılabilmek için eğitim, statü ve maaş başlıkları altında iyileştirmeler yapılmıştır. ${ }^{40}$

SSCB'nin çöküşünü başlangıç olarak kabul edersek, Ukrayna Savaşı'nın vuku bulduğu 2014 yılına kadar geçen 23 yılda icra edilen reformların belli bir aşamaya geldiğini kabul etmek gerekir. Fakat bu gelişimin kolay olmadığını, reform iradesini engelleyen birçok etkenle mücadele edildiğini vurgulamak gerekir. $\mathrm{Bu}$ etkenlerden ilki Rus güvenlik bürokrasisi içerisindeki muhafazakârların keskin muhalefetidir. İkinci engel ise yolsuzlukla mücadele olmuş bu kapsamda yolsuzluk tamamen ortadan kaldırılamamış ama en azından Silahlı Kuvvetler yolsuzluktan büyük ölçüde izole edilmiştir. Üçüncü problem olan, yönetici ve mühendis seviyelerindeki yetişmiş insan eksikliği, hem savunma sanayinin dar görüşlü ve çağdışı kalmasına sebep olmuş hem de ortaya çıkan ürünler, piyasada rekabet edemeyecek kalite ve maliyette kalmıştır. ${ }^{41}$

Rusya, Putin dönemiyle birlikte, emperyal mirasını korumaya çalışan, dolayısıyla bunu mümkün kılacak güce tekrar sahip olmaya gayret eden bir irade göstermektedir. Fakat Çeçenistan ve Gürcistan örneklerinden anlaşıldığı üzere Rusya bu mirası, hem konvansiyonel hem de asimetrik tehditler üretebilecek coğrafi ve toplumsal temeller üzerinde yeniden inşa etmeye çalışmaktadır. Zeminin zor ve kırılgan yapısının yanı sıra birbirinden farklı nitelikteki teşkilatlanmaları ve stratejileri gerektiren bu zor görev, hinterlandını koruma iradesi gösteren Rusya'yı, bütüncül bir güvenlik yaklaşımı benimsemeye zorlamıştır. Ayrıca Gürcistan savaşı, Rusya'ya doğru genişleyen Batının bir sonraki hamlesinden önce inisiyatif alması gerekliliğini de göstererek pasif bir savunma refleksinden, ilk hamleyi yapan proaktif bir güvenlik anlayışını benimsemeye zorlamıştır. 70 yıldır ittifak halinde bulunan NATO'nun varlığ1 göz önünde bulundurulduğunda, proaktif bir güvenlik politikasının en makul yönteminin, sinsi ve inkâr edilebilir hibrit

\footnotetext{
${ }^{40}$ Dale Herspring, agm, s. 47-50.

${ }^{41}$ Andrei Makarychev ve Alexander Sergunin, agm, s. 356-363.
} 


\author{
Rusya'nın Hibrit Savaş Kapasitesinin \\ Kırım ve Donbas Vakaları Üzerinden Analizi
}

saldırılar olduğunu belirtmek mümkündür. Kırım ve Donbas vakaları bu güvenlik politikasının gerektirdiği hibrit yaklaşımın başarılı örnekleri olarak literatürde yerini almıştır.

\title{
4. Kırım ve Donbas Krizlerinin Kronolojisi
}

Hadiselerin arka planını hatırlamak için Ukrayna toplumunun Rus kültürü ile nesillerdir sürdürdüğü tarihi bağları göz önünde bulundurarak, SSCB'nin dağılmasından sonraki siyasi sürece kısaca değinmek gerekmektedir. Bu noktada Kırım'ın statüsünü hatırlamak faydalı olacaktır. 2. Dünya Savaşı sonrasında statüsü Rusya Sovyet Federatif Sosyalist Cumhuriyeti'ne bağlı "özerk cumhuriyet” iken "özerk bölge" olarak değiştirilen Kırım, 1954 yılında Ukrayna Sovyet Sosyalist Cumhuriyeti'ne verilmiştir. $\mathrm{Bu}$ devir dönemin koşulları içerisinde bir jest olarak sunulmuş olsa da arka planda savaşlar ve kıtlıklar sebebiyle ekonomisi ve nüfusu tahrip olmuş Ukrayna'yı teselli etme gayreti görülmektedir. Müteakip süreçte ise Ukrayna'nın 1 Aralık 1991 referandumuyla Sovyetler Birliği’nden ayrılarak bağımsızlı̆̆ını ilan etmesinin ardından Ukrayna sınırları içindeki statüsü değişmeyen Kırım, 21 Ekim 1998 tarihli düzenleme ile Ukrayna'ya bağlı özerk bir cumhuriyet olarak yerel bir meclis tarafından yönetilmeye başlanmıştır. ${ }^{42}$ Ukrayna, bağımsızlığının ardından egemen bir devlet olarak Rusya ile iyi ilişkilerini sürdürmüştür. Başlangıçtaki iyi komşuluk ilişkilerine rağmen Kırım Yarımadası'nın jeostratejik önemi, iki devlet arasında rekabet unsuru olarak varlığını korumuştur. Özellikle Sivastopol Limanı'nın 1997 yılında imzalanan bir mutabakat ile 20 yıllığına Rus Karadeniz Filosu (RKF) için Rusya'ya kiralanmış olması yeni dönemde Rusya'nın Kırım'dan vazgeçmeyeceğinin ilk emaresi olarak okunabilir. Fakat müteakip süreçte Ukrayna hükümetlerinin dış politika tercihleri, yarımadanın akıbeti hakkında Rusya'yı ziyadesiyle tedirgin etmiştir. 2004 y1lındaki Turuncu Devrimle iktidara gelen hükümetin AB ve

\footnotetext{
${ }^{42}$ Fatma Aslı Kelkitli, "Kırım: Rusya için Vazgeçilmez Yarımada”, Hasret Çomak, Caner Sancaktar ve Zafer Yıldırım (ed.), Uluslararası Politikada Ukrayna Krizi, Beta, İstanbul, 2014, 289-309, s. 292-293.
}

221

Güvenlik Stratejileri

Cilt: 17

Say1: 37 
222

Güvenlik Stratejileri

Cilt: 17

Sayı: 37

NATO istikametindeki politikaları ile 2008 yılındaki AB ile serbest ticaret ve ortaklık anlaşması görüşmeleri Ukrayna'nın Batı ile ilişkilerini somutlaştırmıştır.

2010 yılı seçimleri ile Ukrayna'nın Batı ile entegrasyon süreci sekteye uğramıştır. Seçimler neticesinde iktidarı devralan Viktor Yanukoviç, Ukrayna siyasetinin istikametini doğuya çevirmiştir. Batı ile ilişkilerin duraklama devrine girdiği Yanukoviç döneminde, Rusya ile ilişkiler yeniden canlılık kazanmıştır. Örneğin Ukrayna, 1997 yılında imza altına alınan Sivastopol liman kirasını, Rusya'dan ithal ettiği doğal gaz fiyatındaki indirim karşılığında 25 yıl daha uzatmış ve NATO'ya üye olma planından vazgeçmiştir. ${ }^{43} 2013$ yılının sonuna doğru Ukrayna içerisindeki Batı taraftarı toplumun, ülkenin gidişatı ile ilgili rahatsızlığı giderek büyürken, Yanukoviç, ülkenin ekonomik durumunu gerekçe göstererek, $\mathrm{AB}$ ile serbest ticaret ve ortaklık anlaşmasını imzalamayacağını açıklamıştır. Bu açıklamanın ardından, küçük gruplarla başlayan protestolar, sivillerin hayatını kaybetmesiyle beraber meydanların kitleler tarafindan işgal edildiği geniş çaplı protestolara dönüşmüştür. Kırım krizinde kronolojik bir başlangıç belirlemek gerekirse, AB ile köprülerin tek taraflı atıldığı 2013 yılı Kasım ayı, makul bir tercih olacaktır. Hükümetin aldığı karar sonrası başlayan protestolar devam ederken, Yanukoviç, can güvenliği bulunmadığı gerekçesiyle 21 Şubat 2014 tarihinde ülkeyi terk etmiş, ertesi gün Ukrayna Meclisi, hükümet başkanını gıyabında görevden alarak hükümeti düşürmüştür. ${ }^{44}$ Müteakiben, Olexander Turçunov başkanlığında ve Arseniy Yatsenyuk başbakanlığında geçici bir hükümet kurulmuştur. ${ }^{45}$ Rus medyası, Ukrayna'da gelişen olayları, Batı yanlısı faşist bir hükümetin, Yanukoviç'in ardından iktidara

${ }^{43}$ International Partnership for Human Rights, International Crimes In Crimea: An Assessment Of Two And A Half Years Of Russian Occupation, Brussels 2016, s. 13.

${ }^{44}$ BBC, "Ukrainian MPs vote to oust President Yanukovych", https://www.bbc.com/ news/world-europe-26304842 (Erişim Tarihi: 26.09.2018).

${ }^{45}$ Charles K. Bartles ve Roger N. McDermott, "Russia's Military Operation in Crimea", Problems of Post-Communism, 2014, 46-63, s. 54. 


\author{
Rusya'nın Hibrit Savaş Kapasitesinin \\ Kırım ve Donbas Vakaları Üzerinden Analizi
}

gelmesi ve Kırım Yarımadası'nın kaderinin tehlikeye düşmesi şeklinde yorumlamış böylece Rus kamuoyunda, Kırım'a müdahaleyi meşru ve gerekli gören bir alg1 yaratılmıştır. ${ }^{46}$

Kiev'de protestolar sürerken Kırım sokaklarında protestocu halkın yanında tabiiyeti belli olmayan ve askerî disiplinle hareket eden yüzü maskeli silahlı adamlar ortaya çıkmıştır. Rus medyası, yarımadadaki kimliği belirsiz, asker görünümlü silahlı adamları servis etmeye başlamış böylece dünya, maskeli ve silahlı "küçük yeşil adamlar"la (little green men) tanışmıştır. Küçük yeşil adamlar, devlet televizyonu, parlamento, hükümet binaları ve havaalanlarının kontrolünü ele geçirmiştir. Kırım Parlamentosunun 27 Şubat tarihli, silahlar altında icra edilen oturumunda, özerklik koşullarını genişletmeyi öngören bir referandum kararı alınmış ve Anatoli Mogilev başkanlığındaki hükümet görevden alınarak Rusya yanlısı Sergey Aksenov, hükümeti kurma göreviyle başbakanlığa atanmıştır. ${ }^{47} \mathrm{Bu}$ esnada yarımadada kontrolü sağlayabilecek son çare olan Ukrayna askerleri, küçük yeşil adamlar refakatinde halk tarafından kışlalarının içinde tecrit edilmişlerdir. ${ }^{48}$

Kırım'daki siyasi kriz devam ederken, 1 Mart'ta Rusya Devlet Başkanı Putin, Ukrayna sınırları dışındaki etnik Rusların can güvenliğini sağlamak maksadıyla Rusya Silahlı Kuvvetlerini ülke dışında kullanmak üzere Rusya Parlamentosu'na başvurmuştur. ${ }^{49}$ Aynı gün içerisinde Kırım'ın yeni Başbakanı Sergey Aksenov, yarımadada barış ve huzurun tesisi için Putin'den yardım talep etmiştir. Ardından Kırım Parlamentosu, 6 Mart tarihinde tekrar toplanarak, Mayıs ayında yapılması planlanan referandumun, 16 Mart 2014 tarihinde yapılmasını kararlaştırmıştır. ${ }^{50}$

\footnotetext{
${ }^{46}$ International Partnership for Human Rights, International Crimes In Crimea: An Assessment Of Two And A Half Years Of Russian Occupation, Brussels 2016, s. 13.

${ }^{47}$ Reuters, "How the Separatists Delivered Crimea to Moscow", https://in.reuters.com/article/ ukraine-crisis-russia-aksyonov-idINL6N0M93AH20140313, (Erişim Tarihi: 28.09.2018)

${ }^{48}$ Charles K. Bartles ve Roger N. McDermott, agm, s. 55.

${ }^{49}$ President of Russia, "Vladimir Putin submitted appeal to the Federation Council", http://en.kremlin.ru/events/president/news/20353, (Erişim Tarihi: 01.07.2018)

${ }^{50}$ Charles K. Bartles ve Roger N. McDermott, agm, s. 55.
}

223

Güvenlik Stratejileri

Cilt: 17

Say1: 37 
224

Güvenlik Stratejileri

Cilt: 17

Sayı: 37

G7 Liderleri, $A B$ ve AGİT'in planlanan referandumun yasal olmayacağı yönündeki itirazlarına rağmen 16 Mart tarihinde Kırım Tatarlarının büyük oranda boykot ettiği referandum gerçekleşmiştir. Rusya verilerine göre \%81 katılımla gerçekleşen (\%97 lehte oy) referandumdan Rusya'ya katılım kararı çıkmıştır. Bu kararın üzerine Kırım Parlamentosu, Ukrayna'dan bağımsızlığını ilan etmiş ve Rusya'ya katılım kararı almıştır. Referandum kararı, öncesinde olduğu gibi sonrasında da Batı dünyası tarafından kabul görmemiştir. $\mathrm{AB}, \mathrm{BM}$ ve NATO, alınan kararı tanımadıklarını açıklamışlardır. ${ }^{51}$ Referandum sürecini dünyaya yayınlayan Rus medyası, oylamanın demokratik ve barış̧̧ıl bir zeminde gerçekleştiğini belirtse de bu iddiaları teyit eden tarafsız bir kuruluşun olmayışı ve takip eden yıllarda sürece katılan kişilerin itirafları, referanduma gölge düşürmüştür. Referandum kararı alan milletvekillerinin küçük yeşil adamların nezaretinde ve namlunun ucunda oy verdiği ${ }^{52,53}$ ve referanduma katılımın iddia edilenin aksine $\% 30$ oranında kaldığı yönünde haberler mevcuttur. ${ }^{54}$

Kırım'ın Ukrayna'dan ayrilıp Rusya'ya katılması, Donbas'da hükümetin düşmesinden beri protestolarını sürdürmekte olan ayrılıkçılara model olmuş, Kırım ile aynı tarihlerde başlayan ve sokaklarda süren protestolar Mart ayı içerisinde bina işgallerine dönüşmeye başlamıştır. Geçici hükümetin, ayaklanmaya gereken müdahaleyi zamanında

\footnotetext{
${ }^{51}$ International Partnership for Human Rights, International Crimes In Crimea: An Assessment Of Two And A Half Years Of Russian Occupation, Brussels 2016, s. 22.

52 EMPR media, "Russian FSB colonel admits Crimean MPs forced to vote for referendum", https://empr.media/news/russian-fsb-colonel-admits-crimean-mps-forced -to-vote-for-referendum/, (Erişim Tarihi: 29.06.2018)

53 Korrespondent, "В захваченное здание парламента Крыма внесли автоматы Калашникова, снайперские винтовки и гранатометы - очевидец”, https://korrespondent.net/ukraine/politics/3312031-v-zakhvachennoe-zdanye-parlamenta kryma-vnesly-avtomaty-kalashnykova-snaiperskye-vyntovky-y-hranatomety-ochevydets, (Erişim Tarihi: 01.07.2018)

${ }^{54}$ Forbes, "Putin's 'Human Rights Council' Accidentally Posts Real Crimean Election Results", https://www.forbes.com/sites/paulroderickgregory/2014/05/05/putins-humanrights-council-accidentally-posts-real-crimean-election-results-only-15-voted-for-annexa tion/\#3e982bdef172, (Erişim Tarihi: 29.06.2018)
} 


\author{
Rusya'nın Hibrit Savaş Kapasitesinin \\ Kırım ve Donbas Vakaları Üzerinden Analizi
}

gösterememiş olması, ayrılıkçı hareketin ilk aşamada önemli kazanımlar elde etmesini kolaylaştırmıştır. ${ }^{55}$ Donbas'daki protestolar, toplumun beklentilerine cevap veren yerel liderlerin öncülük ettiği doğaçlama bir süreç olarak başlamış gibi görünse de Kırım'daki olayların gelişimine paralel olarak hükümeti doğrudan hedef alan planlı ve kontrollü bir eylem profili çizmiştir.

Ayrılıkçılar Donbas'da kazanımlarını pekiştirirken Kiev, ancak Mayıs sonundaki seçimlerden sonra Donbas'a müdahale iradesi gösterebilmiştir. Yeni hükümet Haziran başında iç güvenliği tekrar tesis edebilmek için Donbas'daki ayrılıkçılara yönelik kapsamlı bir operasyon başlatmış ve Temmuz ayı itibarıyla ayrılıkçıların elinde bulunan bazı endüstri şehirlerini geri almayı başarmıştır. Fakat bu başarılı ivme, Ağustos ayının sonunda, Ilovaysk kasabası yakınlarında ağır bir darbe almıştır. Ayrılıkçıların askerî kapasitesini aşan bu saldırı, Ukrayna birliklerini durdurmuş ve savunma pozisyonuna geçmeye zorlamıştır. Çatışmanın tarafları, meydana gelen zayiattan dolayı yeniden toparlanma ihtiyacı duymuş ve ateşkes gündeme gelmiştir. Sahadaki stratejiyi belirleyen Rusya, altı aydır devam eden iç savaşta gelinen aşamayı diplomasi yoluyla güvence altına almak istemiş ve ayrılıkçılara meşruiyet kazandırabilmek $^{56}$ için Ukrayna ile ateşkes masasına oturmalarını sağlamıştır. Böylece 5 Eylül 2014 tarihinde Minsk-1 mutabakatı imzalanmış ve kısa bir süreliğine ateşkes koşulları tesis edilebilmiştir. ${ }^{57}$

Minsk-1 görüşmeleri ile tesis edilen ateşkes süreci, ayrılıkçılar tarafindan birçok kez ihlal edilmiş ve müteakip süreçte ateşkes koşulları geçerliliğini yitirmiştir. ${ }^{58}$ Çatışan tarafların yükümlülüklerini yerine getirmemeleri, Minsk mutabakatının dışına çıkılması ve muharebe sahasındaki mücadelenin krizi çözüme götürememesi sebebiyle tekrar

\footnotetext{
${ }^{55}$ Charles K. Bartles ve Roger N. McDermott, agm, s. 46.

${ }^{56}$ Hugo Spaulding, "Putin's Next Objectives in The Ukraine Crisis", Institue for The Study of War, 2015, s. 3.

${ }^{57}$ Anna Matveeva, "No Moscow stooges: identity polarization and guerrilla movements in Donbass", Southeast European and Black Sea Studies, 2016, 25-50, s.39

${ }^{58}$ Hugo Spaulding, agm, s. 4.
}

\section{5}

Güvenlik Stratejileri

Cilt: 17

Say1: 37 
226

Güvenlik Stratejileri

Cilt: 17

Sayı: 37

diplomasiye başvurulmuştur. $\mathrm{Bu}$ sefer Almanya ve Fransa da arabuluculuk rolü üstlenmişlerdir. Yaklaşık bir ay süren görüşmelerin ardından oluşturulan Minsk-2 mutabakatı, 11 Şubat 2015'de

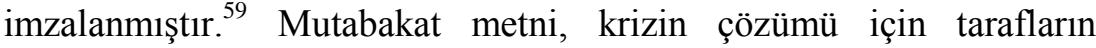
hassasiyetlerini taşıyan kapsamlı bir metin olmasına rağmen tarafların esnemez tutumları süreci açmaza sokmuştur.

\section{Rus Tipi Hibrit Savaşın Boyutları}

Kırım ve Donbas'daki vakaların seyrini takip ettiğimizde ortaya çıkan güvenlik probleminin yerel bir zeminden devletlerarası bir çatışma ortamına transfer olduğu görülmektedir. Krizin neticesi, Soğuk Savaş sonrası dönemde Rusya'nın askerî gücünü açıktan kullandığ 1 birçok vaka ile benzerlik taşısa da yaşanan süreç hem Rusya ile Ukrayna'nın karşılıklı bağları hem de Rusya'nın kullanmayı tercih ettiği millî güç unsurları bakımından farklı bir resmi ortaya koymaktadır. Takip eden başl1klar bu farklılığı ortaya koymaya çalışacaktır.

\subsection{Politik ve Toplumsal Boyut}

Kırım Yarımadası, SSCB dağıldıktan sonra Ukrayna'nın egemenliğinde kalmıştır. Ukrayna'da iktidara gelen 1lımlı hükümetler sayesinde Rusya, yarımadayı Karadeniz Filosu için kullanmayı sürdürmüştür. Fakat kendisine sırtını dönecek bir siyasi iradenin iktidara gelmesi ihtimali, Rusya'yı alternatif plan üretmeye zorlamıştır. Bundan dolayı Rusya, yarımada halkı ile iki asra yakın süren kültürel bağlarını devam ettirmeyi ve toplumda günü geldiğinde Rusya'ya katılmak isteyecek bir kanaat oluşturmayı gerekli görmüştür. ${ }^{60}$

Ukrayna'da toplumsal düzeyde belirli bir kesimin üzerinde coğrafi, tarihi ve kültürel bağlar sebebiyle var olan Rusya nüfuzunun, ${ }^{61}$

${ }^{59}$ Paul Robinson, "Russia's role in the war in Donbass, and the threat to European Security", European Politics and Society, 2016, 506-521, s. 514-515.

${ }^{60}$ Anton Bebler, "The Russian-Ukrainian Conflict Over Crimea", Teorija In Praksa, 2015, 196-219, s. 203.

${ }^{61}$ Michael Kofman ve Matthew Rojansky, “A Closer look at Russia’s "Hybrid War"”, 

ve dış politikasını da kapsayacak şekilde genişlediğini görmek mümkündür. Daha geniş bir perspektifden bakacak olursak, bahsi geçen nüfuzun, Ukrayna'nın SSCB'den ayrıldığı 1991 yılından beri devam ettiğini, yüzünü Batıya döndüğ̈̈ 2004 seçimlerinden sonra genişlediğini, 2010 seçimleriyle pekiştiğini ve 2013'den itibaren geri dönülmez bir yola girdiğini değerlendirmek mümkündür.

Hibrit savaşın toplumsal çerçevesinin, toplum ve yerel idare içerisindeki hassasiyetlerin tespiti ve halk içinde teşkilatlanarak müzahir taban oluşturma aşamalarından oluştuğu görülmektedir. Bu bağlamda, devlet kurumlarının ve toplumun istismar edilmesine yönelik hassasiyetlerin ve zafiyetlerin tespit edilmesi, ilk aşamayı teşkil etmiştir. Müteakiben toplum ve kurumlar nezdinde yapılan tespitleri profesyonel seviyede sürdürebilmek için hedef ülke içerisinde teşkilatlar ve organizasyonlar kurulması gerekmiştir. Bu kapsamda, yarımada halkı ve yönetiminin bütün damarlarına nüfuz etmeyi başarmış bir istihbarat yapılanması $1,{ }^{62}$ özellikle genç kuşağa hitap eden sivil toplum kuruluşları, ${ }^{63}$ üniversiteler ve toplumun muhafazakâr kanadı öncelikli olmak üzere bütün Ortodoks cemaati kucaklayan Ortodoks Kilisesi,${ }^{64}$ toplum içinde asıl kuruluş maksatlarının yanı sıra toplumu şekillendirme misyonu taşıyan ve gerçekleştirilecek hibrit saldırıların toplumsal ve politik boyutunu hazırlayan ve icra eden teşkilatlar olmuşlardır. Bu teşkilatlar Kırım ve Donbas'da, kriz henüz nümayiş seviyesinde iken endişeli ve ayrılıkçı bir taban yaratılmasına zemin hazırlamışlardır. Oluşan endişe, medya ve siyasetçiler aracilığıyla harlanmış ve önce meşru hükümete ve sonra arkasından gelen diğerlerine yönelik bir isyana dönüşmüştür.

Ukrayna'nın parçalanmasına giden sürecin fitilinin "Meydan" (Euromaidan) olayları ile ateşlendiğini belirtmek mümkündür. Fakat

\footnotetext{
The Kennan Institute, 2015, s. 3.

${ }_{62}^{62}$ Anton Bebler, agm, s. 203.

${ }^{63}$ Lada L. Roslycky, "Russia's smart power in Crimea: sowing the seeds of trust", Southeast European and Black Sea Studies, 2011, 299-316, s. 305.

${ }^{64}$ Lada L. Roslycky, agm, s. 310.
}

Güvenlik Stratejileri

Cilt: 17

Say1: 37 
228

Güvenlik Stratejileri

Cilt: 17

Sayı: 37

ironik bir şekilde Meydan protestoları, Rusya'ya sempati besleyen halk tarafından değil bilakis $\mathrm{AB}$ taraftarlarınca başlatılmıştır. Dolayısıyla Hükümeti düşüren ve ülkeyi kaosa sürükleyen olaylar, görünürde Rusya ve Rusya taraftarı toplum tarafindan başlatılmamıştır. $\mathrm{Bu}$ sebeple Rusya'yı sıcağı sıcağına fail ilan etmek mümkün olmamıştır. Diğer bir ifade ile Moskova, hibrit savaşın politik boyutunu başlatmasına rağmen bu hamleyi $\mathrm{AB}$ taraftarlarına yaptırarak hem hedef ülke hem de uluslararası kamuoyunun gözünde geri planda kalmış ve karş1 grubun eylemleri için gerekçe oluşmasını sağlamıştır. $\mathrm{Bu}$ örnek, hibrit saldırıların, failini belli etmeden hedef toplum üzerinde başarıyla etkili olduğunu göstermesi bakımından önem arz etmektedir.

2013 yılının sonunda başlayan protestolar büyüyerek devam etmiştir. AB taraftarı protestoculardan hayatını kaybedenler olmuş, Rusya taraftarı protestocular da sokağa dökülerek yangının harlanmasına, toplumun keskin hatlarla kutuplaşmasına sebep olmuştur. ${ }^{65}$ Eylemler sürerken Rus medyası, çeşitli basın yayın platformları üzerinden bilgi kirliliği yaratmak suretiyle toplumu endişeye sevk etmiştir. ${ }^{66}$ Hükümet karşıtı protestolar, bölgeye önceden sızdırılmış olan üniformasız özel kuvvetler unsurlarının kılavuzluğunda bina işgallerine dönüşmüş ve böylece barışç1 gösteriler, devlet otoritesinin fiziksel anlamda işlevsiz hale geldiği iç savaş koşullarına evrilmiştir. Birçok noktada meydana gelen işgaller, geçici hükümeti, kontrolü çok zor bir iç güvenlik problemi ile karşı karşıya bırakmıştır.

Rusya için Kırım'daki başarının teminatı sürat olmuştur. Yanukoviç'in azledilmesiyle hükümetin düştüğü 22 Şubat'tan referandumun icra edildiği 16 Mart'a kadar geçen iki buçuk haftalık süre içerisinde, tek bir silah patlamadan süreç tamamlanmıştır. Yarımadada olan biten hakkında sihhatli, objektif bilgi alamayan uluslararası kamuoyu, kolektif bir duruş oluşturamamış ve 1991'de Litvanya'nın bağımsızlık

${ }^{65}$ Radio Free Europe/Radio Liberty, "Pro-Russian Separatism Rises In Crimea As Ukraine's Crisis Unfolds", https://www.rferl.org/a/ukraine-crimea-rising-separatism/ 25268303.html, (Erişim Tarihi: 27.09.2018)

${ }^{66}$ Michael Kofman ve Matthew Rojansky, agm, s. 5. 
sürecindeki ile eşdeğer ağırlığı olan bir tepki gösterememiştir. Rusya ise hem Ukrayna yönetimine hâkim olan kaos durumundan hem de yarımada içerisinde titizlikle tertiplendirilen küçük yeşil adamlarından istifade ederek süratle yarımadayı Ukrayna'dan çekip almıştır. Bu bağlamda, Rusya'nın yarımadada yıllarca faaliyet gösteren teşkilatlarının temellerini attığı yolsuzluk tohumlarının, devlet otoritesi sarsılmaya başladığında, etkili hibrit hamlelere dönüştüğü görülmektedir. Kırım'ın kaderinin yeniden belirlendiği bu süreçte, Kiev'de görevi henüz devralmış bir geçici hükümetin tam olarak siyasi iradesini kuramaması ve başkomutan profili ortaya çıkartamamasından dolayı yarımadaya hâkim olan siyasi belirsizliğin, yarımadadaki güvenlik güçlerinin davranışlarına da tesir etmiş olduğu görülmektedir.

\subsection{Askerî Boyut}

Yanukoviç hükümetinin düşmesinin ardından ilan edilen geçici hükümetin daha ilk günlerinde, yarımadanın birçok yerinde ortaya çıkan sivil grupların eylemleri, çok kısa bir süre içerisinde küçük çaplı sokak protestolarından, organize ve maksatlı eylemlere dönüşmüştür. Bu gruplar, kimlik kontrolü, hükümet ve medya binalarının ele geçirilmesi gibi eylemler ile yerel idare ve kolluğun vazifesini üstlenmişlerdir. Hatta devletin asayişi ve iç güvenliği tesis etmek için kolluktan sonra başvurabileceği son kuvvet olan Ukrayna ordusunun askerleri de kışlalarında halk görünümlü aynı gruplar tarafindan tecrit edilmiştir. Halkın belirli bir kısmı, adaya dışarıdan gelen sivil grupların öncülüğünde yerel idare ve medya kuruluşlarının binalarını işgal ederek yarımadanın genel kontrolünü sağlarken, meclisin kontrolü özel kuvvetler unsurları tarafından gerçekleştirilmiştir. Çünkü yarımadanın kaderini belirleyecek ve Rusya silahlı kuvvetlerini yarımadaya davet edecek olan yasama organının denetimi ve kontrolü, düzensiz sivil gruplara bırakılmayacak kadar büyük önem arz etmiştir. ${ }^{67}$

\footnotetext{
${ }^{67}$ Gregory F. Treverton vd., Addressing Hybrid Threats, Swedish Defence University, Stokholm, 2018, s. 16.
} 
Kırım'da iki buçuk hafta içerisinde olup biten olaylar

Güvenlik Stratejileri

Cilt: 17

Sayı: 37 değerlendirildiğinde, harekâtı başarıya götüren en titiz iki müdahalenin, Ukrayna askerlerinin kışlalarında zaptedilmesi ve meclisin arzu edilen kararları alacak şekilde kontrol altına alınması olduğunu belirtmek mümkündür. Her iki eylemde de halkın katılımı, sergilenen yöntemin hibrit boyutunu göstermesi bakımından önem arz etmektedir. $\mathrm{Bu}$ bağlamda icra edilen halk tabanlı hibrit hamle, üç sebepten dolay1 özgündür. Öncelikle, yarımadada halkın da katılımıyla gerçekleşen sivil savunma eylemleri, bölgeye bu maksatla gelmiş olan sivil grupların desteği ve belirli bir maske altında orada bulunan Rus güvenlik görevlilerinin yönetimi altında gerçekleşmiştir. Zaten yarımadada ikamet eden Slav kökenli Ortodoks Ukrayna vatandaşları bahsi geçen grupların tetiklemesi ile halkın meşru müdafaası imajını yaratmıştır. İkinci sebep, meclis gibi kritik noktalarda gerçekleşen eylemlerin, hataya mahal vermemek için sivil kıyafetli Rus güvenlik görevlileri (özel kuvvetler unsurları) tarafından yürütülmüss olmasıdır. Son olarak, yarımadada basının tek temsilcisi kalan Rus medyası, sokak eylemlerini dünyaya yayınlarken halkın belirli bir kesimine odaklanmış ve muhalif protestoları kadrajın dışında bırakmak suretiyle yarımadanın Rusya'ya geçiş sürecini desteklemiştir.

Ukrayna ve Kırım'da siyasi irade kontrolünü kaybederken, Rus askerleri, sessiz manevralarla yarımadaya yerleșmeye başlamışlardır. $\mathrm{Bu}$ hassas tertiplenme sürecinin büyük bir gizlilikle yürütülmesi, Kırım harekâtının kaderini belirleyen sürpriz faktörünün başarıyla uygulanmasını sağlamıştır. Örneğin, 7-23 Şubat 2014 tarihleri arasında icra edilen Kış Olimpiyatları, her ne kadar Soçi şehrinde icra edilse de müsabakaların genel güvenliğini sağlamak üzere bölgeye yerleştirilen özel kuvvetler birliklerinin tertiplenmesi için makul bir gerekçe sağlamıştır. Ayrıca Sivastopol limanında konuşlu bulunan Rus Karadeniz Filosu da (RKF) tertiplenme safhasının önemli bir üssü olmuştur. RKF'nin yasal varlığı, limana getirilen takviye birlikleri, harekât gününe kadar emniyetli bir şekilde saklamıştır. Rusya'nın Ukrayna sınırlarında icra ettiği beklenmedik tatbikatlar, hem paraşütçü birliklerin sınırı geçerek Ukrayna topraklarına fiilen yerleşmesini maskelemiş hem de Ukrayna'nın geçici 
Rusya'nın Hibrit Savaş Kapasitesinin

Kırım ve Donbas Vakaları Üzerinden Analizi

hükümetini askerî anlamda baskı altına alan konvansiyonel güç gösterileri olmuştur. ${ }^{68}$

22 Şubat'ta hükümetin düşmesi ile 16 Mart'ta referandumun icra edilmesi arasında geçen süre, Kırım'ın ilhakı için en kritik süreci oluşturmuştur. Bu süreçte yarımadanın, kara, hava ve deniz ulaşımının kesilerek tecrit edilmesi ve bu esnada yarımadada sürecin kontrolden çıkmasına sebep olabilecek tek silahlı güç olan Ukrayna askerlerinin kontrol altında tutulması, hibrit savaşın askerî boyutunun riskli ve bir o kadar da profesyonel safhasını oluşturmuştur. $\mathrm{Bu}$ süreçte kışlaların etrafı halk ile kuşatılmış böylece geçici hükümetle irtibatı kesilen askerlerin silahsız halk ile karşı karşıya gelmesi sağlanmıştır. Hatta askerlerin taraf değiştirmesini teşvik etmek için donanma komutanının taraf değiştirmesi ${ }^{99}$ basın aracılığıyla servis edilmiş ve işgal süresince Rus askerleri tarafindan müzakereler sürdürülmüştür. ${ }^{70}$ Söz konusu tecrit sadece karadaki üslerle sınırlı kalmamış denizde de aynı prensip uygulanmıştır. Ukrayna sahil güvenliğinin bulunduğu Balaklava Limanı'nın girişine Rus donanma gemileri demirlemiş, Ukrayna donanmasının bir kısmının bulunduğu Donuzlav körfezi çıkışında da iki Rus gemisi kasten batırılarak körfeze giriş ve çıkışlar bloke edilmiştir. ${ }^{71}$

RKF, yarımadada, hibrit savaş kapsamında çok önemli bir rol oynamışır. RKF'ye atfedilen rolü, demografik yapının şekillendirilmesi ve tertiplenme olmak üzere iki başlık altında incelemek mümkündür. Hatırlanacağı üzere RKF'nin yarımadaya konuşlanma tarihi, Kırım'ın Rusların egemenliğine girdiği 1783 tarihine tekabül etmektedir. RKF, Ukrayna'nın bağımsızlığını ilan ettiği tarihten sonra bile limanı terk

\footnotetext{
${ }^{68}$ President of Russia, "Vladimir Putin answered journalists' questions on the situation in Ukraine", http://en.kremlin.ru/events/president/news/20366, (Erişim Tarihi: 28.09.2018)

${ }^{69}$ The Guardian, "Ukraine navy officers reject plea to defect to Russian-backed Crimea", https://www.theguardian.com/world/2014/mar/03/ukraine-navy-officers-defect-russiancrimea-berezovsky, (Erişim Tarihi: 26.09.2018)

${ }^{70}$ Michael Kofman vd., Lessons from Russia's Operations, Rand, Santa Monica, 2017, s. 9.

${ }^{71}$ International Partnership for Human Rights, International Crimes In Crimea: An Assessment Of Two And A Half Years Of Russian Occupation, s. 18-19.
}

231

Güvenlik Stratejileri

Cilt: 17

Sayı: 37 
etmemiş ve Rus kimliğini sürdürmüştür. Yarımadada görev yapmış

Güvenlik Stratejileri

Cilt: 17

Sayı: 37 birçok Rus denizci emekli olduktan sonra Kırım'a yerleşmiş ve bu emeklilik tercihleri yarımadada azımsanmayacak bir Rus nüfusun türemesine sebep olmuştur. 1783 yılında yarımada nüfusunun yarıdan fazlasını oluşturan Kırım Tatarlarının, muhtelif dönemlerde sürgüne gönderildiği ve yarımada içerisindeki nüfus oranlarının büyük ölçüde azaldığı göz önünde bulundurulduğunda, Kırım halkını temsil eden emekli Rus bahriyelilerin azınlık sayılamayacağını belirtmek mümkündür. ${ }^{72}$ Etnik grupların genel nüfus içerisindeki dağılımı Kırım Yarımadası'nın Rus nüfuzuna girdiği tarihten itibaren istikrarlı olarak Rusların lehine değişmiştir. Resmî olarak güncelliğini koruyan fakat yaklaşık 20 yıl öncesine dayanan verileri incelediğimizde dahi yarımadadaki Rus etnik grubun yarıdan fazla olduğu görülmektedir. 2001 nüfus sayımına (2001'den bu güne nüfus sayımı yapılmamıştır.) göre Kırım'ın 2.024.000 nüfusu içerisinde \%58,3 Rus, \%24,3 Ukraynalı ve $\% 12$ Kırım Tatarı'nın bulunduğu görülmektedir. ${ }^{73}$ RKF'nin yarımadadaki varlığının bir diğer avantajı da tertiplenme olmuştur. ${ }^{74}$ Filonun yasal varlığ 1 ve özerk yapısı sayesinde, yarımadayı kontrol almak üzere limana önceden yerleştirilen askerler, harekâtın başladığı güne kadar gizlilik içerisinde saklanabilmiş böylece olaylar başlayıp bütün dikkatler yarımadaya çevrildikten sonra dışarıdan adaya doğru tepki çekebilecek büyük çaplı birlik kaydırmalarına ve intikallere gerek kalmamıştır. Başka bir ifadeyle RKF, kalenin içten fethedilmesine büyük bir katkı sağlamıştır.

Donbas cephesinde ayrılıkçıların kısa süre içerisinde birçok şehirde devlet otoritesini kurabilmesinin en önemli sebeplerinden birisi, bu seviyedeki bir nümayişe karşı kullanılabilecek olan askerî birliklerin ülkenin doğusundaki garnizonlarda zayıf kuvvetlerden müteşekkil

72 Lyudmila Beybulayeva, The "Crimean Question" In Russo-Ukrainian Relations 1991-2014, Yüksek Lisans Tezi, Atılım Üniversitesi, Ankara, 2015, s. 23.

${ }^{73}$ Ukrayna Devlet İstatistik Kurumu Resmî Sayfası, "National composition of population", http://2001.ukrcensus.gov.ua/eng/results/general/nationality/ (Erişim Tarihi: 23.01.2021)

${ }^{74}$ Gregory F. Treverton, age, s. 20. 


\author{
Rusya'nın Hibrit Savaş Kapasitesinin \\ Kırım ve Donbas Vakaları Üzerinden Analizi
}

olmasıdır. Ukrayna içerisinde bulunan askerî üsler, SSCB'nin NATO'ya karşı oluşturulan savunma planları çerçevesinde batıda güçlü, doğu ve güneyde zayıf olacak şekilde konumlandırılmışlardır. Ukrayna, bağımsızlıktan sonra bu tertiplenmeyi bütçe sınırlamalarından dolayı değiştirememiş, dolayısıyla doğu ve güneydeki garnizonlar devlet otoritesinin sadece kolluk ile temsil edildiği şehirler olarak kalmıştır. Ayrıca 2014-2015 yıllarındaki çatışmaların ateşkes molalarından anlaşılacağı üzere, Ukrayna ordusunun eğitimi ve harbe hazırlık seviyesi, olması gereken seviyenin altındadır. Yıllardır müşterek tatbikat yapmamış, modern silah teçhizattan yoksun ve zorunlu askerlerden oluşan ordu, ülke sınırları içerisindeki çatışmalarda, paramiliter kuvvetlere karşı iki kez ateşkes masasına oturmak zorunda kalmıştır. ${ }^{75}$

Kiev'de iktidarı devralan geçici hükümetin, Donbas mıntıkasında asayişi tesis etme çabaları başlangıçtan itibaren başarısız olmuştur. Ukrayna askerleri kendi vatandaşlarına karşı silah kullanmak istememiş hatta askerlerden ayrılıkçıların saflarına katılanlar bile olmuştur. $\mathrm{Bu}$ süreçte ayrılıkçılar, referandum düzenleyerek Donsetsk'te ve Luhansk'da bağımsızlıklarını ilan etmişlerdir. Bu kopuş süreci ancak 25 Mayıs seçimleri neticesinde bir devlet başkanının göreve gelmesiyle durdurulabilmiş böylece Ukrayna silahlı kuvvetleri bir başkomutan önderliğinde toparlanma firsatı bulmuş ve ilk harekât, Donetsk Havaalanı'na gerçekleştirilmiştir. ${ }^{76}$ Seçimler sonucu oluşan siyasi irade ile toparlanan Ukrayna ordusu, ayrilıkçılar karşısında kazanımlarını pekiştirmeye başlamış ve başlangıçta kaybedilen toprakların bir kısmını geri alabilmiştir. Bu esnada Rusya, Ukrayna ordusunun ilerleyişi ve kazanımları karşısında, Temmuz ayından itibaren askerî varlığını belirgin bir şekilde artırmıştır. Rusya tarafından, Donbas cephesindeki Rus askerî varlığı inkâr edilmesine rağmen Ağustos ayında Rus paraşütçüler, Ukrayna askerleri tarafindan Ukrayna sınırları içerisinde yakalanmıştır. ${ }^{77}$ Bu bağlamda Rusya'nın Donbas krizine katılımının iki

\footnotetext{
${ }^{75}$ Paul Robinson, agm, s. 506-521.

${ }^{76}$ Gregory F. Treverton, age, s. 23-24.

77 The Washington Post, "Ukraine detains Russian paratroopers; U.S. ambassador warns of
}

\section{3}

Güvenlik Stratejileri

Cilt: 17

Say1: 37 
boyutu olduğunu belirtmek mümkündür. Birinci boyut muharebe sahasının şekillendirilmesidir. Aslen, sahadaki mücadelenin kaderini,

Güvenlik Stratejileri

Cilt: 17

Say1: 37 çatışmaların tarafları olan ayrılıkçılar ve Ukrayna güvenlik kuvvetleri belirlemiş fakat Rusya, sağladığı ateş desteği, silah ve teçhizat yardımı ve lider personel desteği ile neticeyi şekillendiren irade olmuştur. Ağustos sonundaki Ilovaysk muharebelerinde görüldüğ̈ üzere ayrıllkçılara verilen yardımın bir frekansı vardır ve bu frekans, çatışan tarafların bir plan doğrultusunda kazanmalarını veya kaybetmelerini sağlamaktadır. Meselenin ikinci boyutu, ayrılıkçılara meşru bir statü kazandırmaktır. Bu maksatla taraflar Minsk görüşmelerinde masaya oturmuş ve pazarlık sürecine geçmiştir. Fakat tarafların taviz vermeyen tutumları, somut bir sonuca götürmemiş ve çatışmalar sürmüştür. Rusya, uyguladığ 1 hibrit savaşın gereği olarak konvansiyonel kuvvetlerini açıktan kullanmamış, perde arkasından desteklemiş ve istikrarlı bir biçimde örtülü olarak sağladığı askerî desteğini inkâr etmiş̧ir. Böylelikle 2014 yılının Temmuz ayından itibaren Donbas cephesinin, taşeron kuvvetlerinin savaştığ bir vekâlet savaşına evrildiği görülmektedir.

\subsection{Ekonomik Boyut}

Rusya'nın enerji ve borç kozunu, 2014'den önce Ukrayna hükümetlerinin bağımsız iradeleri üzerinde kontrol sağlamak için kullandığını görmek mümkündür. Rusya'nın ihraç ettiği gazın fiyatında veya miktarında yaptığı değişiklikler ile Ukrayna'nın borçları üzerinden gerçekleştirdiği manevralar, her dönemde Ukrayna hükümetlerinin halk ile karşı karşıya gelmesine sebep olmuş, doğal gaz vanalarının kış mevsiminin en soğuk aylarında kesilmesi, siyasi iradeyi her seferinde ödün vermeye zorlamıştır.

29 Kasım 2013'de Yanukoviç, AB ile Serbest Ticaret Anlaşmasını, ekonomik koşulların daha da kötüleşeceği endişesiyle imzalamamıştır.

"counter offensive"”, https://www.washingtonpost.com/world/putin-will-meet-withukrainian-counterpart-in-high-stakes-summit-amid-tense-situation/2014/08/26/875db4035b7b-4d89-8443-5aee1bde6345_story.html?noredirect=on\&utm_term $=.593775 \mathrm{e} 9 \mathrm{f} 3 \mathrm{c} 8$, (Erişim Tarihi: 26.09.2018) 
Dolayısıyla ülkeyi kaosa götüren ilk hamleyi, ucuz gaz ve kredileri koz olarak kullanan Rusya'nın ekonomik saldırıları karşısında Ukrayna'nın almak zorunda kaldığı bir karar olarak kabul etmek mümkündür. Yanukoviç, Rusya'dan aldığı gazın ve kredinin fiyatlarındaki artışı dengeleyemeyeceğini değerlendirerek kamuoyundaki beklentinin aksine ekonomik anlaşmadan çekilmiştir. ${ }^{78}$ Yanukoviç Hükümetinin yerine gelen geçici hükümet, ülkenin doğusu ve güneyindeki ayrılıkçı hareketlerle baş etmeye çalışırken Rusya, Yanukoviç döneminde teklif ettiği kredi vaadini geri çekmiş ve geciken ödemelerin yapılmasını talep ederek yeni hükümet üzerindeki baskısını artırmıştır. Ayrıca Rus enerji şirketi Gazprom da kış mevsiminde doğal gaz fiyatlarını artırmış $^{79}$ böylece geçici hükümetin maruz kaldığı hibrit saldırılara ekonomik derinlik de eklenmiştir.

\subsection{Bilgi Savaşı, Internet ve Sosyal Medya Boyutu}

Propaganda, savaş tarihi içerisinde derin kökleri olan bir taktiktir. Toplumların, liderlerin ve askerlerin algılarını şekillendirmek için zihinlerde oluşturulan kanaatler, hedef kitlenin karar verme sürecini etkileyerek "Bilgi Savaşı" olarak adlandırılan yöntemin en temel bileşenini oluşturmaktadır. Bilgi savaşlarının kapsamı, teknikleri, safhaları, derinlemesine incelenmesi gereken geniş bir yelpazeye yayılmıştır. Hibrit savaş kapsamı içerisinde bilgi savaşı, sıkça başvurulan bir yöntem olup teknolojik gelişmelere paralel olarak çeşitliliğini ve etkinliğini muazzam ölçüde genişletebilmiştir. İnternetin olmadığı Soğuk Savaş döneminde toplumda bir kanaat oluşturmanın yegâne aracı televizyon, radyo ve gazeteler olmuş, bir haberi bu kanallara yerleştirip toplumla buluşturmak da bugüne kıyasla muazzam ölçüde emek ve zaman gerektirmiştir. Günümüzde ise neredeyse internetin girmediği hane, cep telefonuna sahip olmayan birey kalmamıştır. Dolayısıyla doğru kanallarda hazırlanan etkili mesajları hedef kitleye ulaştırmak ve geri besleme almak

\footnotetext{
${ }^{78}$ Gregory F. Treverton, age, s. 57.

79 Politico, "Tensions flare over Russia-Ukraine gas deal", https://www.politico.eu/ article/russia-gazprom-ukraine-trilateral-sefcovic/, (Erişim Tarihi: 02.10.2018)
}

235

Güvenlik Stratejileri

Cilt: 17

Say1: 37 
daha kolay hale gelmiş̧ir. Alışık olduğumuz tabirle propagandanın her yerde olduğu, savaş bir kenara, para harcama alışkanlıklarımızın bile takip

Güvenlik Stratejileri

Cilt: 17

Say1: 37 edildiği ve iştahlandırıldığı günümüzde, bilgi savaşlarının çok önemli ve yaygın bir kabiliyet haline geldiği görülmektedir.

2014 Şubat ayında Kırım Yarımadası'ndaki telekomünikasyon tesisleri maskeli ve silahlı adamlar tarafindan saldırıya uğramış, bu sebeple yarımadada televizyon yayını, internet ve telefon servisi kesilmiştir. ${ }^{80}$ Böylece Ukrayna medyası, hem teknik kabiliyetleri karşı ataklarla kısıtlandığı hem de küresel Rus medyasının yanında cılız kaldığı için sesini duyuramamıştır. Gösterici gruplar, binaları işgal ederek kontrolü ele geçirmeye başladıkları ilk andan itibaren yarımadaya giriş ve çıkışlar kapatılmış ve Rus askerleri bütün yayıı kuruluşları üzerinde tam bir kontrol sağlamıştır. Böylece Moskova mahreçli yayınların haricinde başka yayınlar yapılması engellenmiştir. ${ }^{81}$

Yanukoviç hükümetinin meşruiyetini kaybetmesinin ardından sahadaki askerî manevralarla eş zamanlı olarak medya kuruluşları üzerinden iki farklı hedef kitleye yönelik bir bilgi savaşı başlatılmıştır. Öncelikli hedef kitle olan Rus kamuoyuna, Ukrayna'da iktidarı devralan geçici hükümetin, darbeci-faşist bir hükümet olduğu vurgulanmış ve Kırım'da hayatları tehlike altında olan başta etnik Ruslar olmak üzere bütün Kırım halkının can güvenliklerin sağlanması gerektiği ve bu vazifenin maliyetinin toplum tarafindan karşılanmasının bir gereklilik olduğu algısı işlenmiştir. Bu iç propaganda ile eş zamanlı olarak dışarıya yönelik de kapsamlı bir çerçeve çizilmiş, Uluslararası kamuoyu, Batı dünyasının dilinden yapılan yayınlarla hibrit savaşın en kritik dönemi olan iki haftalık referandum sürecinde başarıyla oyalanmıştır. ${ }^{82}$

${ }^{80} \mathrm{CSO}$, "Are we witnessing a cyber war between Russia and Ukraine? Don't blink - you might miss it", https://www.csoonline.com/article/2913743/cyber-attacks-espionage/arewe-witnessing-a-cyber-war-between-russia-and-ukraine-dont-blink-you-might-miss-it.html, (Erişim Tarihi: 02.10.2018)

${ }^{81}$ Gregory F. Treverton, age, s. 18.

${ }^{82}$ Michael Kofman vd, age, s. 13. 


\author{
Rusya'nın Hibrit Savaş Kapasitesinin \\ Kırım ve Donbas Vakaları Üzerinden Analizi
}

Rus medyası tarafindan internet ve televizyon platformlarından Batı dünyasına yönelik yapılan yayınlar, Kırım ve Donbas sokaklarındaki eylemleri başarıyla çarpıtmış ve yönlendirmiştir. Servis edilen içerikler, Ukrayna'da demokrasinin koruyucusunun Rusya olduğu temasinda birleşmiş, başta $A B D$ ve NATO olmak üzere Batı dünyası, Ukrayna ve Rusya'nın egemenliğine müdahale etmekle suçlanmıştır ve Ukrayna'daki geçici hükümetin darbe ile iktidara gelen faşist bir hükümet olduğu mesajı işlenmiştir. ${ }^{83}$ Yaratılan suni gündemler, Rus medyasının küresel yayın gücü sayesinde geniş kitleleri peşinden sürükleyebilmiştir. Örneğin, Meydan ${ }^{84}$ protestolarının Nazi yanlısı gruplar tarafindan organize edildiği ve bu sebeple Yahudilerin Ukrayna'da hedef haline getirilebileceği mesajı verilerek Yahudi cemaati üzerinden güvensizlik ve kaos atmosferine hizmet edecek yayınlar yapılmıştır. Başka bir haberde ise Ukrayna hükümetinin, Donbas'da yürütülen askerî harekât hakkında batılı bir düşünce kuruluşundan yardım istediği ve bahse konu kuruluşun, Donbas'da etnik temizlik yapılmasını tavsiye ettiği yönünde bir sahte haber üretilmiştir. $\mathrm{Bu}$ sahte haber, Ukrayna ordusunun kazanımlarını artırdığı dönemde dolaşıma sokulmuş ve uzun süre gündemi işgal etmiştir. Bir örnek daha vermek gerekirse, karadan havaya atılan bir hava savunma füzesi ile vurularak 298 sivilin hayatını kaybetmesi ile sonuçlanan MH17 uçağı vakası da Rus medyasının propaganda malzemesi olmuştur. Ukrayna hava savunma sistemlerinin, Putin'in uçağını düşürmeye çalışırken MH17 uçağını düşürdüğü iddiası, bağımsız kaza raporu çıkana kadar gündemde tutularak Ukrayna ordusunun profesyonelliği ve yeterliliğinin sorgulanmasına sebep olmuştur. Hâsılı, Rusya'nın medyadaki gücü, hem sahadaki diğer hibrit saldırılarını gizlemiş veya bulandırmış hem de

\footnotetext{
${ }^{83}$ Peter Pomerantsev ve Michael Weiss, The Menace of Unreality: How the Kremlin Weaponizes Information, Culture and Money, The Institute of Modern Russia, New York, 2014, s. 30.

${ }^{84}$ Ukrayna vatandaşları tarafından, Hükümetin AB'ye ilişkin kararlarını protesto etmek amacıyla, 2013 Kasım- 2014 Şubat tarihleri arasında vuku bulan ve başkan ile hükümetin düşmesi ile sonuçlanan toplumsal gösteriler.
}

\section{7}

Güvenlik Stratejileri

Cilt: 17

Say1: 37 

birçok kritik süreçte rakibinin karar verme kabiliyetini sekteye uğratabilmiştir. ${ }^{85}$

Rusya'nın uyguladığı hibrit saldırılar sadece basın üzerinden bilgi savaşları ile sınırlı kalmamış siber saldırılar da gerçekleştirilmiştir. Örneğin 2013-2015 yılları arasında Ukrayna hükümetini hedef alan üç büyük siber saldırıdan birisi, 2014'ün ikinci yarısındaki seçim sonuçlarının açıklanmasını ertelemiş, böylece ülkenin ihtiyacı olan siyasi istikrar yaklaşı dört ay ötelenmiştir. ${ }^{86}$ Ayrıca sosyal medya hesapları üzerinde de Rus hâkimiyetini görmek mümkündür. Nitekim Meydan gösterileri esnasında protestocuların sıklıkla kullandığı, sunucuları Rusya'da bulunan VKontakte ve Odnoklasssniki isimli sosyal medya platformlarına erişim gereken zamanlarda engellenmiştir. Aynı platformlar Donbas çatışmaları esnasında Ukrayna askerlerinin aleyhine olacak şekilde, Rusya'nın istihdam ettiği trol ordusu tarafindan aktif olarak kullanılmıştır. Bu kapsamda bahse konu platformlar tarafindan askerlerin teslim olmalarını teşvik eden, cephedeki komutanların birliklerini terk ettiği, birliklerin geri çekildiği türden teslimiyetçi mesaj ve içerikler üretilmiş̧ir. ${ }^{87}$ Rusya, SSCB'nin dağılışından beri özel bir önem göstererek geliştirdiği Rus medyasını, küresel seviyede başarıyla kullanmıştır. Harekât boyunca Batı medyasının hedef kitlesine Batılıların dilinde yayın yapan Rus medya kuruluşları, sahada olup bitenleri başarıla perdelemeyi ve dünyaya istedikleri gibi aktarmayı başarmıştır. İnternet trollerinin de desteğiyle Batı medyası yalan ve yanlış haberlerle karmaşaya sevk edilmiştir. ${ }^{88}$

\footnotetext{
${ }^{85}$ Peter Pomerantsev ve Michael Weiss, age, s. 31.

${ }^{86}$ Gregory F. Treverton, age, s. 28.

${ }^{87}$ Gregory F. Treverton, age, s. 28.

${ }^{88}$ András Rácz, Russia's Hybrid War in Ukraine Breaking the Enemy's Ability to Resist, The Finnish Institute of International Affairs, Helsinki 2016, s. 51-53.
} 


\author{
Rusya'nın Hibrit Savaş Kapasitesinin \\ Kırım ve Donbas Vakaları Üzerinden Analizi
}

\section{Sonuç}

\section{9}

Ukrayna coğrafyasındaki mücadeleyi, tarihi, ekonomik, jeostratejik köklerini de göz önünde bulundurmak koşuluyla, güvenlik bilimleri literatüründe çoğunluğun mutabık olduğu üzere hibrit savaş olarak tanımlamak mümkündür. Bu noktada hibrit savaş kavramına kapsayıcı ve genel bir tanım çizmek gerekirse en az üç temel özelliğini vurgulamak gerekmektedir. Geleneksel tehdit algısının dışındadır, hedefin zafiyetlerine odaklanır, eylemlerini dikkat çekmeden ve tespit edilmeden gerçekleştirir. ${ }^{89} \mathrm{Bu}$ üç özellik müteakip paragraflarda detaylandırılmıştır.

Özellikle Batı dünyasında, Soğuk Savaşın ardından benimsenen güvenlik konseptine göre devlet nezdinde tehdidin iki yönlü olduğu ve iç ve dış olmak üzere birbirinden ayrıldığı görülür. ${ }^{90}$ Bu ayrım, tehditle mücadele için gereken metotları ve teşkilatları şekillendirir. Devletler, güvenlik mekanizmalarını tehdit algısındaki kabullere göre inşa ederler. Geleneksel güvenlik konseptine göre tehditler, henüz olgunlaşmadan tespit edilerek, pasif tedbirler ve zamana yayılan sistemsel çözümler ile bertaraf edilmeye çalış1lır. Bertaraf edilemeyen tehdit, kriz ve çatışma safhalarına ulaştığında alınacak tedbirin şiddeti ve sürati de artar. $\mathrm{Bu}$ kademelendirme içerisinde hibrit tehditler ve saldırılar, geleneksel güvenlik konseptinin tespit radarının altında kalan saldırılar olarak cereyan eder. Bu tür saldırıların dozajının düşük olması, birbirinden farklı alanlarda eş zamanlı vuku bulması ve değişken bir tempo ile gerçekleşmesi, tespit edilmesini zorlaştırır. Kırım'da küçük yeşil adamlar ile Donbas'daki taşeron gruplar, Ukrayna Devleti'nin ve NATO'nun öngördüğ̈̈ tehdit tanımlamasının dışında kalmıştır. $\mathrm{Bu}$ bağlamda Rusya, hibrit savaşı uygulayan devlet aktörü olarak harekât bölgesine

${ }^{89}$ Patrick J. Cullen ve Erik Reichborn-Kjennerud, Understanding Hybrid Warfare, 2017, s. 7-8.

${ }^{90}$ Didier Bigo, "When Two Become One: Internal and External Securitisations in Europe", M. Kelstrup, \& M. Williams (Eds.), International Relations Theory and The Politics of European Integration. Power, Security and Community, Routledge, 2000, 171 - 204, s. $171-172$.
Güvenlik Stratejileri

Cilt: 17

Say1: 37 
240

Güvenlik Stratejileri

Cilt: 17

Sayı: 37 geleneksel tehdit algısının dışında kalan piyonlar sokarak rakiplerini hazırlıksız yakalamayı başarmıştır.

Hibrit savaş aktörü hedefine tek bir kabiliyet ile değil birbirinden farklı kabiliyetleri harmanlayarak saldırır. Yöntemde çeşitlilik gerektiren bu tür bir yaklaşım, şüphesiz hedefin farklı cephelerine, yani farklı zafiyetlerine odaklanmayı gerektirir. Dolayısıyla etkili bir hibrit savaş paketinin kapsamı, hedef ülkenin askerî kapasitesine ilaveten toplumsal, ekonomik ve diğer beşeri sektörlerdeki hassasiyetleri içerir. Bu sebeple hedefin zafiyetlerini sadece konvansiyonel ordusunun içinde aramak, hibrit savaş konsepti içinde çok dar bir alt başlığa saplanmak anlamına gelmektedir. Hedef ülkenin bürokrasisi, toplumun etnik ve dini yapısı, ülkenin ekonomik sistemi, enerji kaynakları ile kaynak ve nakil bağımlılı̆̆ı, silahlı kuvvetlerinin muharip gücü, komşuları ile olan ilişkileri ve sorun sahaları, toplumu oluşturan kimliklerin diaspora bağları gibi konu başlıkları hibrit savaşın yöneleceği ve istismar edeceği cepheleri oluşturmaktadır. Hedef ülke içerisinde ne kadar çok zafiyet var ise o ülkenin kapsamlı bir hibrit saldırı karşısında o kadar kırılgan bir hedef haline gelebileceğini belirtmek mümkündür. Nitekim Rusya hasmına, geçici hükümetin ülkeyi idare etmeye çalıştığ zamanda, bütün zafiyetlerin azami ölçüde istismar edilebileceği siyasi bir buhran dönemi içerisinde müdahale etmeyi tercih etmiştir.

Hibrit saldırılar acı eşiğinin altında kalarak gerçekleştirilir. Bu sebeple savunan tarafın, kendisine yönelik saldırıyı fark etmesi, dolayısıyla ne olduğunu anlaması güçtür. Başka bir deyişle saldıran taraf, eylemlerinin dozunu ve çeşidini, hedefinin gündeminde ilk sırayı alacak seviyeye çıartmaz. Bu sebeple problemin tespiti zordur ve krizin ilerleyen safhalarında fark edilse bile ülke içi tepkinin ve uluslararası dayanışmanın oluşmasını da geciktirir. Görüldüğü üzere Kırım ve Donbas vakaları, uzun yıllara sirayet eden toplumsal ayrışma temelinin üzerine öncelikle ekonomik baskılarla başlamış, müteakiben hükümetin düşmesi ile politik bir kriz oluşturulmuş ve sahadaki silahlı unsurların modern bir cephe savaşını devam ettirdiği bir vekâlet savaşına evrilmiştir. Hibrit savaşın, sınır hattındaki vekâlet savaşına dönüşmeye başladığı Minsk mutabakatları öncesinde, Ukrayna'nın 
üzerinde oturduğu fay hatlarını analiz etmek veya tedbir almak mümkün olmamıştır.

Netice itibariyle hibrit savaş yönteminin, mucizevî bir keşif olmadığını vurgulamak gerekmektedir. Fakat tehdidin sinsi ve kapsamlı niteliğine karşı da savunan taraf olarak teyakkuzda bulunmak, saldıran taraf olarak ise sunduğu coğrafi ve toplumsal avantajları göz önünde bulundurmak gerekmektedir. Çünkü hibrit savaş, çok bileşenli olduğu için dinamiktir, gelişmektedir ve tabi ki coğrafyaya ve zamana göre farklı özelliklerin öne çıkacağı özgün bir yöntemdir. Hibrit savaş olarak adlandırılan usul, stratejik amacın elde edilmesi için önceden beri bilinen ve kullanılan yöntemlerin, zaman ve mekân sınırlaması olmaksızın ortak bir üst aklın yönetiminde icra edilmesini ve uluslararası tepki çekmeden hayata geçirilmesini gerektirmektedir. $\mathrm{Bu}$ yöntemlerin başarılı olması da saldıran tarafın becerisinin yanı sıra savunan tarafin zayıf kalmasından kaynaklanmaktadır.

\section{Summary}

War is always being developed by its soldiers and generals. Science and method are both main guides to the victory in the competition for triumph. It is impossible to draw boundaries to the creativity but effort to define the limits for a methodology is a necessity in order to understand the phenomenon. In the fight on the battlefield, the weak side has always been the one whose success depends on its creativeness. The concept of asymmetry derives from this premise. If we need to determine a starting point, it would probably dates back until the first clashes of civilization. As an example, the written history gives the successful example of Hannibal against the massive army of the Roman Empire. In modern times academia study both the conventional examples of World War 2 and the unconventional examples of the Cold and the Limited Wars. With the addition of regional battles that has occurred after the Cold War, warfare literature recorded a wide array of different implementations of the existing rules and forms. Apart from conventional definitions of warfare, the concept of asymmetry is a field with lots of unique cases as well as different descriptions. So it is possible to accept the "asymmetric warfare" 
242

Güvenlik Stratejileri

Cilt: 17

Sayı: 37

term as an umbrella title. Under this generic title, hybrid warfare is assumed to be the specific and current interpretation of the modern conflict. Despite the hardship to define every unique conflict, the necessity to analyse the performance, forecast the concept and update the doctrine is the analytical and professional approach for modern and strong armies.

The main topic of this study sets an example of the struggle between the relative weak and the relative strong in terms of hybrid warfare. In Crimea and Donbas, Russian side preferred to choose a stealthy course of act. With this insidious approach she acted as the relative weak unlike the coalition forces who acted conventionally and blatantly in Iraq, in 2003. On the other hand, the other side which portrayed the image of relative strong was the western coalition and US with their strict alliance. As a single state and against the concrete western bloc, Russia tried to implement a multidisciplinary way of action, employed a variety of proxy actors and covered all the process with her prevalent media. This so called way of hybrid approach includes a versatile action, timing, coordination of all military and non-military institutions of Russian State, society and religious institutions

With the annexation of Crimea and forming the stalemate in Donbas, Russia reached her strategic goals such as halting potential expansion of western alliance, securing her hinterland and changing the statue of Crimean Ports towards her own sovereignty. This success didn't solely achieved by the Russian side as a player on the ground. The battlefield made an important contribution to the outcome in favour of Russia. Most importantly the historical and religious background of the eastern and southern regions of Ukraine played a decisive role for the quick success. The Communist Party shaped both the administrative cycles and the culture of community in these regions for decades. Moreover, imperial heritage and the Orthodox Church caused deep cultural transformations on people for centuries. Comparing the impact of 26 years old independent Ukrainian State with the century Old Russian heritage on people's mind will help us to figure out the preferences of local people in the region.

The Russian way of hybrid warfare can be seen as a genuine example of its geography, people, culture and historical background. 


\author{
Rusya'nın Hibrit Savaş Kapasitesinin \\ Kırım ve Donbas Vakaları Üzerinden Analizi
}

Keeping in mind the difficulty to define the exact boundaries for a battle which is seen blurry and has a cause and effect relationship within a complex structure, every specific hybrid case includes unique traits in itself. What this study has tried to reflect is to demonstrate the distinctive manner of the Russian way of Hybrid Warfare.

243

Güvenlik Stratejileri

Cilt: 17

Say1: 37

\title{
KAYNAKÇA \\ Kitaplar
}

BİGO, D. (2000). When Two Become One: Internal and External Securitisations in Europe. In M. Kelstrup, \& M. Williams (Eds.), International Relations Theory and The Politics of European Integration. Power, Security and Community (pp. 171 - 204). Routledge

FERRIL, A. (1985). The Origins of Warfrom the stone age to alexander the great. London: Thames and Hudson Ltd.

GAYDAY, A. (2011). Reform of the Russian Army. In M. Barabanov, Russia's New Army (pp. 10-12). Moscow.

HOFFMAN, F. G. (2007). Conflict in the 21 Century: The Rise of Hybrid Wars. Arlington, Virginia: Potomac Institute for Policy Studies.

Kara Kuvvetleri Komutanlığı, TSK Hibrit Harekat Konsepti, Kara Kuvvetleri Basımevi Müdürlüğü, Ankara 2017.

KELKİTLI, F.A.(2014). Kırım: Rusya için Vazgeçilmez Yarımada, Hasret ÇOMAK, Caner SANCAKTAR ve Zafer YILDIRIM (ed.), Uluslararası Politikada Ukrayna Krizi, 289-309, Beta

RÁCZ, A. (2016). Russia's Hybrid War in Ukraine. Helsinki: The Finnish Institute of International Affairs .

TREVERTON, G. (2018). Addressing Hybrid Threats. Swedish Defence University.

U. S. Command, (2015). "Little Green Men": A Primer on Modern Russian Unconventional Warfare, Ukraine 2013-2014. North Carolina: The United States Army Special Operations Command Fort Bragg.

U. S. Command, (2010). IRREGULAR WARFARE: COUNTERING IRREGULAR THREATS . JOINT OPERATING CONCEPT. ABD.

The Military Doctrine of the Russian Federation. (2010, 2 5). Moskova: Russian Federation presidential edict.

Makaleler

BARTLES, C., \& McDermott, R. N. (2014). "Russia's Military Operation in Crimea". Problems of Post-Communism, pp. 46-63.

BEBLER, A. (2015). The Russian-Ukrainian Conflict Over Crimea. Teorija In Praksa, pp. 196-219. 
244

Güvenlik Stratejileri

Cilt: 17

Sayı: 37
BOOT, M. (2013). The Evolution of Irregular War: Insurgents and Guerrillas From Akkadia to Afghanistan. Foreign Affairs, pp. 100-114.

BUNKER, R. J. (1999). Unconventional warfare philosophers. Small Wars \& Insurgencies, pp. 136-149.

CALHOUN, Mark T (2011). CLAUSEWITZ AND JOMINI Contrasting Intellectual Frameworks in Military Theory, Army History, 22-37

CIOFFI-REVILLA, C. (1996). Origins and Evolution of War and Politics. International Studies Quarterly, pp. 1-22.

Complex Irregular Warfare: The Face of Contemporary Conflict, The Military Balance. (2011, 04 12). The Military Balance.

CULLEN, P., \& Kjennerud, E. (2017). Understanding Hybrid Warfare, . A Multinational Capability Development Campaign Project, 7-8.

GERASIMOV, V. (2016). The Value of Science Is in the Foresight New Challenges Demand Rethinking the Forms and Methods of Carrying out Combat Operations . Military Review, 23-29.

GREGORY, P. R. (2014, 05 05). Putin's 'Human Rights Council' Accidentally Posts Real Crimean Election Results. Retrieved 06 29, 2018, from Forbes: https://www.forbes.com/ sites/paulroderickgregory/2014/05/05/putins-human-rights-council-accidentally-posts-realcrimean-election-results-only-1

HERSPRING, D. (2008). Russian Military Reform and Anatoly Serdyukov. Problems of Post-Communism, pp. 20-32.

HERSPRING, D. (2013). Anatoly Serdyukov and the Russian Military. Problems of Post-Communism, pp. 42-58.

HOFFMAN, F. G. (2009). Hybrid Warfare and Challenges. JFQ, pp. 34-39.

HOFFMAN, F. G. (2009). Hybrid Warfare and Challenges. Joint Force Quarterly, 34-39. HUD, Bohdan (2016). Ukrainian Greek Catholic Church in Galicia (Halychyna): The Creation, The Ban, And The Resurrection. Generall Overview, Proceedings of History Faculty of Lviv University, 273-293

IPHR. (2016). International Crimes In Crimea: An Assessment Of Two And A Half Years Of Russian Occupation. Brüksel: International Partnership for Human Rights.

JANMAAT, Jan Germen (2005). Ethnic and Civic Conceptions of the Nation in Ukraine's History Textbooks, European Education, 20-37

JANOS, A. C. (1963). Unconventional Warfare: Framework and Analysis. World Politics, Vol. 15, pp. 636-646.

KEANE, C., \& Diesen, G. (2017). The Two-tiered Division of Ukraine: Historical Narratives in Nation-building and Region-building. Journal of Balkan and Near Eastern Studies, 315.

KOBER, Avi (2005). Does the Iraq war reflect a phase change in warfare?, Defense \& Security Analysis, 123

KOFMAN, M. (2017). Lessons from Russia's Operations. santa monica: RAND Corporation.

KOFMAN, M., \& Rojansky, M. (2015). "A Closer look at Russia's "Hybrid War"”. The Kennan Institute. The Kennan Institute. 
Rusya'nın Hibrit Savaş Kapasitesinin

Kırım ve Donbas Vakaları Üzerinden Analizi

KUZİO, Taras (2001). Historiography and National Identity among the Eastern Slavs: Towards a New Framework, National Identities, s. 109-132.

KUZİO, Taras (2005). Nation Building, History Writing and Competition Over The Legacy of Kyiv Rus in Ukraine, Nationalities Papers, 29-58

LELE, a. (2014). Asymmetric Warfare: A state vs non-state conflict. oasis, 97-111.

MAKARYCHEV, A., \& Sergunin, A. (2013). Russian military reform: institutional, political and security implications. Defense \& Security Analysis, pp. 356-364.

MATTIS, J. N., \& Hoffman, F. (2005, vol.132). Future Warfare: The Rise of Hybrid Wars. Proceedings, 1-2.

MATVEEVA, A. (2016). No Moscow stooges: identity polarization and guerrilla movements in Donbass. Southeast European and Black Sea Studies, pp. 25-50.

MONAGHAN, A. (2015). Putin's Way of War: The War' in Russia's Hybrid Warfare. Parameters, pp. 65-74.

POMERANTSEV , P., \& Weiss, M. (2014). The Menace of Unreality: How the Kremlin Weaponizes Information, Culture and Money. New York: The Institute of Modern Russia.

ROBİNSON, P. (2016). Russia's role in the war in Donbass and the threat to European security. European Politics and Society, 506-521.

ROSLYCKY, L. L. (2011). Russia's smart power in Crimea: sowing the seeds of trust. Southeast European and Black Sea Studies, pp. 299-316.

SALMONI, B. (2007). The Fallacy of 'Irregular' Warfare. The RUSI Journal.

SCHROEFL, J., \& Kaufman, S. (2014). Hybrid Actors, Tactical Variety: Rethinking Asymmetric and Hybrid War. Studies in Conflict \& Terrorism, pp. 862-880.

SHULMAN, S. (1999). The cultural foundations of Ukrainian national identity. Ethnic and Racial Studies, 1011-1036.

SPAULDING, H. (2015). Putin's Next Objectives in The Ukrane Crisis. Backgrounder, 1-10. İnternet Kaynakları

Anonym. (2014, 02 22). Ukrainian MPs vote to oust President Yanukovych. Retrieved 09 26, 2018, from BBC news: https://www.bbc.com/news/world-europe-26304842

Britannica, T. E. (2016, 02 22). Kievan Rus. Retrieved 11 14, 2018, from Encyclopædia Britannica: https://www.britannica.com/topic/Kievan-Rus

Britannica, Donets Basin. Retrieved 01 23, 2021, from Encyclopædia Britannica: https://www.britannica.com/place/Donets-Basin

В захваченное здание парламента Крыма внесли автоматы Калашникова, снайперские винтовки и гранатометь - очевидец. (2014, 02 27). Retrieved 0701 , 2018, from Korrespondent: https://korrespondent.net/ukraine/politics/3312031-vzakhvachennoe-zdanye-parlamenta-kryma-vnes

Russia Recognizes Abkhazia, South Ossetia. (2008, 08 26). Retrieved 07 20, 2018, from Radio Free Europe/Radio Liberty): https://www.rferl.org/a/Russia_ Recognizes_Abkhazia_South_Ossetia/1193932.html

Russian FSB colonel admits Crimean MPs forced to vote for referendum . (2015, 01 27). Retrieved 07 29, 2018, from EMPR.media : https://empr.media/news/russian-fsbcolonel-admits-crimean-mps-forced-to-vote-for-referendum/ 


\section{Gökhan CİN - Hasan Hüseyin TEKİN}

246

Güvenlik

Stratejileri

Cilt: 17

Sayı: 37

Ukrayna Devlet İstatistik Kurumu Resmî Sayfas1, Retrieved 01 23, 2021, "National composition of population", http://2001.ukrcensus.gov.ua/eng/results/general/nationality/ Ukraine, S. (n.d.). Chronology of the Hetmanate: 1552-1795. Retrieved 11 14, 2018, from Sovereign Ukraine: https://sovereignukraine.net/all/history/chronology-of-ukraine-15521795/

T.C. Dışişleri Bakanlığı Resmî İnternet Sayfası, Ukrayna'da son durum ve ikili ilişskiler, Retrieved 01 23, 2021, http://www.mfa.gov.tr/ukrayna_da-son-durum-veikili-iliskiler.tr.mfa

Tensions flare over Russia-Ukraine gas deal. (2015, 09 14). Retrieved 10 02, 2018, from Politico: https://www.politico.eu/article/russia-gazprom-ukraine-trilateral-sefcovic/

Vladimir Putin answered journalists' questions on the situation in Ukraine. (2014, 0304$).$ Retrieved 09 28, 2018, from President of Russia: http://en.kremlin.ru/events/ president/news/20366

Vladimir Putin submitted appeal to the Federation Council. (2014, 03 01). Retrieved 07 01, 2018, from President of Russia: http://en.kremlin.ru/events/president/news/20353

www.worldhistory.biz, E. o. (2015, 08 11). Galicia-Volhynia. Retrieved 11 14, 2018, from WorldHistory: https://www.worldhistory.biz/contemporary-history/76035-galiciavolhynia.html 